\title{
7. PROVENANCE AND GLACIAL HISTORY OF VERY FINE QUARTZ SAND FROM THE WEDDELL SEA, ANTARCTICA ${ }^{1}$
}

\author{
C. H. Smith ${ }^{2,3}$ and S. B. O’Connell ${ }^{2,4}$
}

\begin{abstract}
Very fine quartz sand was examined from Paleogene and Neogene sediments of ODP Sites $693,694,695,696$, and 697 to determine their grain roundness using Fourier analysis and SEM surface texture characteristics. The objective of this study was to identify grain roundness and surface texture characteristics unique to East (Site 693) and West (Sites 695,696 , and 697) Antarctica and to glacial regimes. Once identified, these distinguishing features could then be used to determine changes in source area and glacial conditions in the central Weddell Sea Basin (Site 694).

Three end members of very fine quartz sand are recognized in the Oligocene to Pleistocene sediments of the Weddell Sea: angular, rounded, and intermediate. End member 1 (angular) consists of extremely angular grains with numerous fracture textures. Previous investigations suggested that these sands are derived from crystalline rocks that fractured during formation or deformation and/or were exposed to weathering by ice. In this study, however, the correlation of angularity with ice activity is problematical as the most angular sands were recovered in the lower Oligocene sediments of the South Orkney Microcontinent, a period of temperate climatic conditions. End member 3 (rounded) consists of rounded grains with chemically and mechanically produced surface textures. These sands are presumed to be derived from the Beacon-type rocks in East Antarctica and the sedimentary deposits of the Northern Antarctic Peninsula. End member 2 (intermediate) grains display crystalline nodes and grain embayments. They are thought to be derived from felsic intrusives, East Antarctic quartzites, basement metamorphics of the South Orkney Microcontinent, and/or the Andean intrusive series of West Antarctica.

Unfortunately, no features unique to either the East or West Antarctic sediment sources or to glacial conditions could be isolated. Therefore, the objective of determining provenance changes and sediment erosion and transport mechanisms could not be achieved using this approach.
\end{abstract}

\section{INTRODUCTION}

\section{Technique}

One of the primary objectives of ODP Leg 113 was to investigate the extent of cryospheric changes in and around Antarctica. This study was designed to contribute to this objective by investigating the effect of glacial and interglacial changes on the clastic marine sedimentary record. Very fine quartz sand was analyzed with a quantitative and relatively new sedimentologic technique, Fourier grain shape analysis, supplemented by scanning electron microscope (SEM) surface texture analysis. In prior studies, Fourier analysis (shape) has been successfully used to determine provenance, and to a lesser extent transport history, and SEM studies (texture) have been used to indicate transport history.

Both SEM textural and Fourier shape analysis are relatively new sedimentologic tools based on the premise that microscopic textural features and shapes of clastic particles can be used to determine a particle's chemical and physical history. Beginning in the late 1960's-early 1970's, SEM surface texture identification was applied to distinguish between sedimentary environments (e.g., Krinsley and Doornkamp, 1973). Although widely used in the 1970's, this technique fell into relative disuse in the early 1980's, in part because of time and equipment limitations; analysis of a single 100-grain sample takes a full day and requires expensive, specialized equipment (Krinsley and Marshall, 1987).

\footnotetext{
${ }^{1}$ Barker, P. F., Kennett, J. P., et al., 1990. Proc. ODP, Sci. Results, 113: College Station, TX (Ocean Drilling Program).

2 Department of Oceanography and Ocean Drilling Program, Texas A\&M University, College Station, TX 77840.

${ }^{3}$ Present address: Minerals Management Service, 949 E 36th Avenue, Anchorage, AK 99508.

4 Present address: Department of Earth and Environmental Sciences, Wesleyan University, Middletown, CT 06457.
}

In contrast, mathematical techniques such as Fourier and fractal analyses are relatively fast and require relatively inexpensive electronic data processing and storage systems. Fourier analysis of sedimentary particles uses a summation of sines and cosines to characterize the boundary of a grain, which is interpreted as providing provenance and transport history (Ehrlich and Weinberg, 1970; Mazzullo et al., 1982). The combination of SEM surface texture and Fourier analysis provides a natural complement for solving geologic problems. Fourier analysis can be used to evaluate a wide variety of samples. Results of Fourier analysis can be given geologic significance through SEM studies of specific representative samples, much like "ground truthing" (Ehrlich et al., 1987).

The application of SEM surface texture and Fourier analysis is based on the assumption that the shapes of quartz grains are a function of both the manner in which they formed and the processes to which they have been exposed, either concurrent with or subsequent to their liberation from the parent rock (Moss, 1966; Mazzullo and Magenheimer, 1987). These complementary techniques have been applied in a wide variety of geologic environments (e.g., Hudson and Ehrlich, 1980; Mazzullo and Ehrlich, 1980; Mazzullo et al., 1982; Mazzullo, 1986).

Prior to this study, Margolis and Kennett $(1970,1971)$ used SEM surface texture analysis to identify sand-grain textures associated with specific glacial environments. In the early stages of SEM analysis the presence or absence of conchoidal fractures, comminution debris, and arcuate steps was used as criteria for determining glacial or nonglacial environments. However, a number of subsequent studies have reported similar textures on grains derived from crystalline bedrock (Mazzullo and Magenheimer, 1987). Rather than the presence of "glacial textures" it is the intensity of fracturing and the presence of "glacial textures" that distinguishes grains from glacial environments from grains derived from crystalline bedrock (Dowdeswell et al., 1985; Ritter, 1987). 
A number of studies have used Fourier grain shape analyses to quantify the grain shape characteristics of cold environments. Dowdeswell (1982) showed that englacial grains are more angular and rougher than basal grains. Mazzullo and Anderson (1987) used both grain shape and surface texture to distinguish till from glacial marine sands in the Weddell and Ross Seas, but with only limited success. Fourier grain shape and surface texture analyses have also been used to define glacial-interglacial cycles (Dowdeswell et al., 1985; Eggers and Ehrlich, 1987).

The specific objectives of this study were twofold: (1) to determine the provenance and transport history of clastic sediments in the Weddell Sea through a study of the shapes and surface textures of very fine $(63-125 \mu \mathrm{m})$ quartz sand; and (2) to combine the Fourier grain shape and surface texture data with chronostratigraphic data to estimate when major glacial changes occurred.

\section{Regional Geology}

The Weddell Sea is bounded by both East and West Antarctica. The two geologic provinces are separated by the Pensacola Mountains, which are part of the Transantarctic Mountain Range (Fig. 1).

The East Antarctic Province consists of upper Precambrian and lower Paleozoic continental crust which was folded, metamorphosed, intruded by granites, and peneplaned in the middle Paleozoic (Craddock, 1982). Subsequent to peneplanation tectonic movement was negligible. Overlying the thick peneplane surface are thick sequences of middle Paleozoic through Mesozoic flat-lying sediments, intruded by basic igneous rocks, with local outcrops of extrusive volcanics.

Located in western Dronning Maud Land, the Ahlmann Ridge is separated from the adjacent crystalline shield by deep crustal

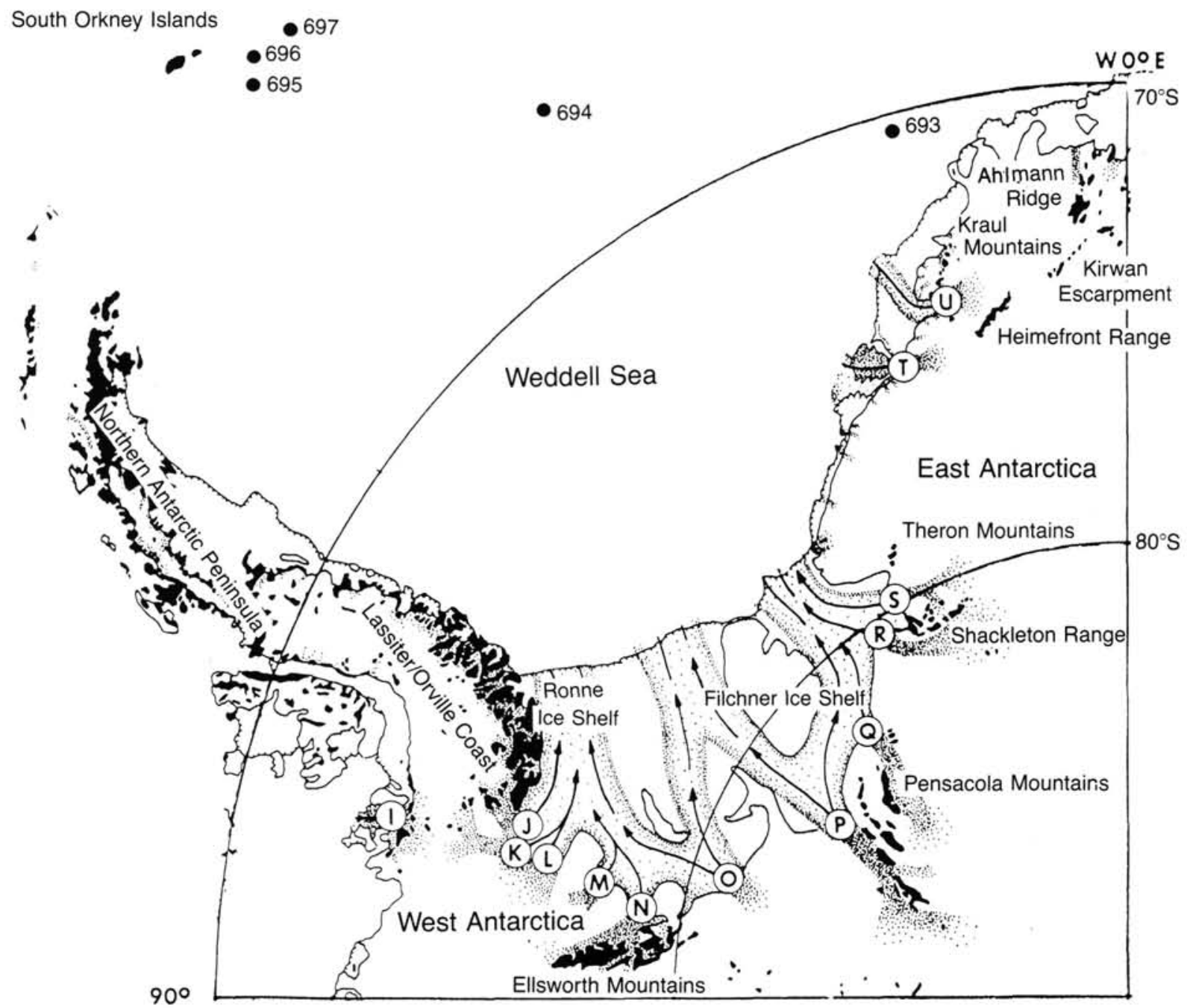

Figure 1. East and West Antarctic geologic provinces separated by the Pensacola Mountains, which are part of the Transantarctic mountain range. Black areas identify scattered local outcrops. Letters I through U identify the major glaciers and ice streams draining these mountainous regions (modified from Hughes, 1977). 
faults. The exposed rocks consist of nonmetamorphosed, subhorizontal, nearshore sediments and intercalated andesitic lava intruded at different times by mafic, ultramafic, and felsic intrusive rocks (Neethling, 1972; Breddell, 1982). Directly south of the Ahlmann Ridge, the Kirwan Escarpment exposes Precambrian crystalline basement, lower and upper Paleozoic metamorphosed sedimentary rocks, and Jurassic basaltic lava flows (Aucamp et al., 1972).

The Heimefront Range contains exposures of Precambrian basement and the Jurassic Beacon Supergroup, which consists of cross-bedded feldspathic sandstones, arkoses, and Glossopteris-bearing shales. The Kraul (Vestfjella) Mountains expose Permian continental clastic sediments, Jurassic (?) basic lavas and volcaniclastics, and post-volcanic dolerite and olivine gabbro (Hjelle and Winsnes, 1972). The Beacon Supergroup, Devonian to Jurassic cross-bedded feldspathic sandstones, arkoses, and coal-bearing shales, is exposed in the Theron Mountains.

The East Antarctic basement complex is exposed in the Shackleton Range by the Shackleton Range Metamorphic Complex (Parkhurst et al., 1983). Unconformably overlying the metamorphics, the Cambrian Turnpike Bluff Group consists of quartzite, quartzose sandstone, argillaceous siltstone, and pebble conglomerate. The Blaiklock Glacier Group overlies the Turnpike Bluff Group and consists of sandstone and shale with a pebble conglomerate (Clarkson, 1982).

The West Antarctic province, although generally composed of younger rocks, also has a complex and varied geologic history consisting of widely deformed and metamorphosed lithologies. The Antarctic Peninsula is a remnant of a linear magmatic arc related to the subduction of the Pacific Ocean floor (Thomson et al., 1983). The basement of this arc is largely unknown as its outcrops consist primarily of metasedimentary rocks, gneisses, and igneous plutons.

The Ellsworth Mountains contain a series of Paleozoic sedimentary rocks ranging in age from Cambrian to Permian. One period of low-grade regional metamorphism and intensive folding has affected all of the rock units (Bauer, 1983).

The Lassiter/Orville Coast region outcrops include tightly folded geosynclinal clastic rocks intruded by plutons, predominantly granodiorite and adamellite (Laudon et al., 1983; Rowley et al., 1983). The northern Antarctic Peninsula basement consists of (1) regionally metamorphosed Precambrian schists and gneisses; (2) the Carboniferous Trinity Peninsula Group, composed of graywackes, mudstones, and siltstones; and (3) Mesozoic rhyolites, andesites; and marine sedimentary rocks (Adie, 1962; Elliot and Trautman, 1982).

Northeast of the tip of Antarctica, the basement of the South Orkney Islands is formed by the Coronation Metamorphic Complex, consisting of quartz mica schists, amphibolites, and marbles. Carboniferous graywacke and Mesozoic conglomerates overlie basement (Thomson, 1974). The varied geologic environments of West Antarctica contain many sources for sandsize quartz grains.

\section{LEG 113 SITE LOCATIONS}

The Weddell Sea represents a potentially unique environment for collecting sediments derived from the East and West Antarctic ice sheets. Site 693 (Fig. 2) was defined as representative of East Antarctic sources, and Sites 695, 696, and 697 were defined as representative of West Antarctic sources. If these two provinces could be distinguished, then it would be possible to evaluate the contribution of East and West Antarctic sediments to Site 694 , in the central abyssal plain.

The origin of the sediments in the central basin (e.g., Site 694 ) is problematic. Anderson et al. (1986) show that turbidite sands from the central abyssal plain are enriched in quartz and contain fewer lithic grains than slope deposits. They conclude
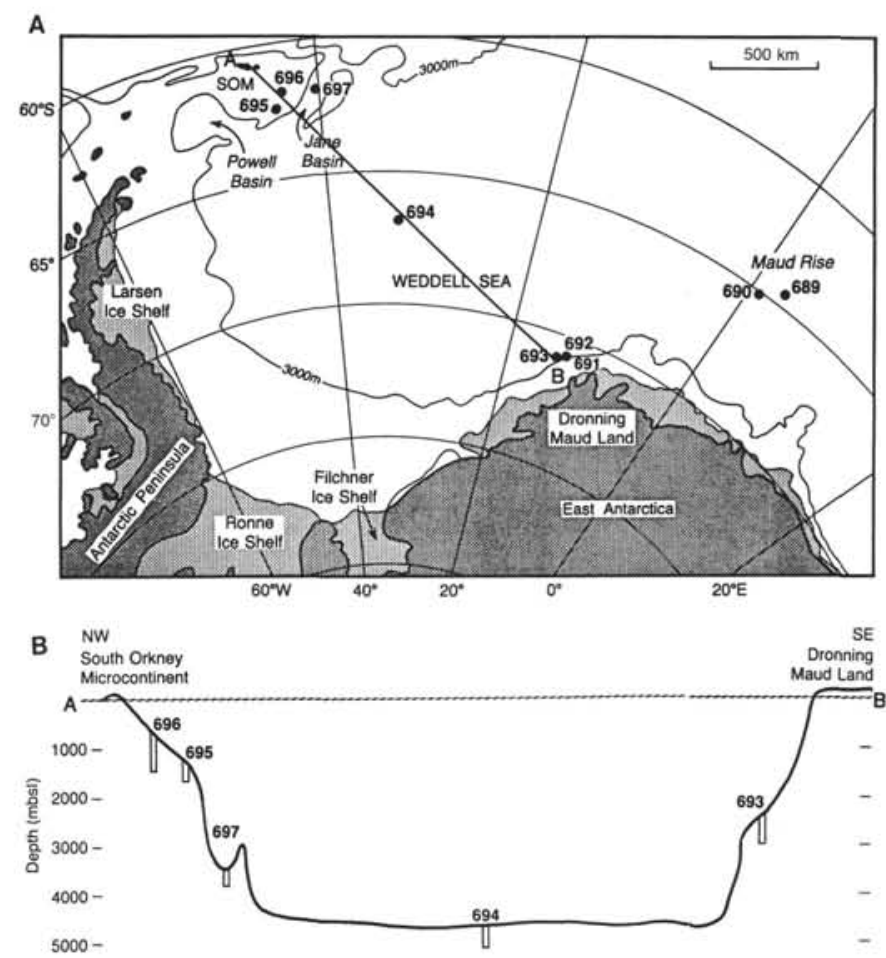

Figure 2. A. Location of Leg 113 Sites 689-697 in the Weddell Sea. SOM $=$ South Orkney Microcontinent. B. Schematic northeast-southwest transect across the Weddell Sea showing the relative position and depth distribution of Sites 693-697; from Shipboard Scientific Party (1988).

that the abyssal sediments show greater mineralogic maturity and are derived from a well-sorted East Antarctic source during more temperate glacial conditions, when the maritime setting included glacial outwash streams and beaches. In contrast, Leg 113 drilling results suggest that the origin of these central basin sediments is from West Antarctic sources, based on lithic grains thought to have been derived from the Jurassic and Cretaceous sedimentary rocks of the southern Antarctic Peninsula (Shipboard Scientific Party, 1988).

Examination of temporal changes in the sources of sediment to the central basin (Site 694) during the growth of the East Antarctic Ice Sheet (EAIS) and the West Antarctic Ice Sheet (WAIS) should provide a representative chronology for the influence of the ice sheets. As the initiation and growth of these ice sheets had different histories, documenting the contribution of sediment from each source area through time would allow evaluation of temporal source changes.

\section{Lithologies}

Five sites drilled on ODP Leg 113, Sites 693-697, were sampled for this study. The other four sites were not sampled because either terrigenous sand-size material was absent (Sites 689 and 690) or core recovery was too poor (Sites 691 and 692). Lithologic descriptions of these sites follow (Fig. 3). The sediment classification scheme is the one adopted by the Leg 113 Shipboard Party (Shipboard Scientific Party, 1988). Chronostratigraphic data are based on the Berggren et al. (1985) time scale from the published site reports (Shipboard Scientific Party, 1988).

The Oligocene to Pleistocene sediments of Site 693 on the Dronning Maud Land margin consist dominantly of hemipelagic muds (Fig. 3A). Five lithologic units were defined (Ship- 
A

Siliceous Biogenic Sediments

PELAGIC SILICEOUS BIOGENIC - SOFT

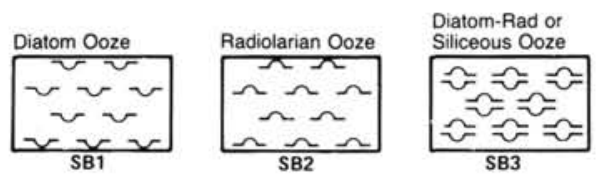

PELAGIC SILICEOUS BIOGENIC . HARD
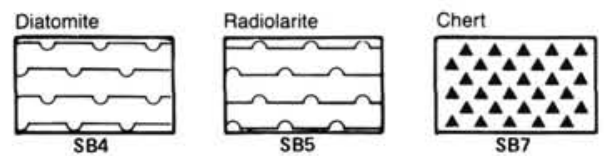

SB7

TERRIGENOUS SEDIMENTS

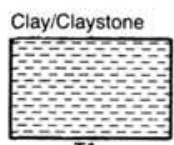

T1

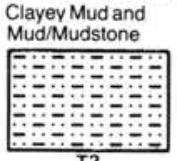

Sandy Mud/
Sandy Mudstone

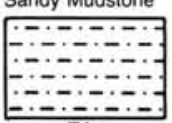

Sand/Sandstone

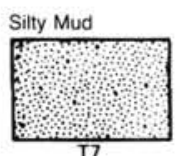

Gravel

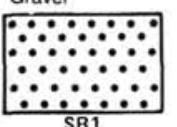

SR1

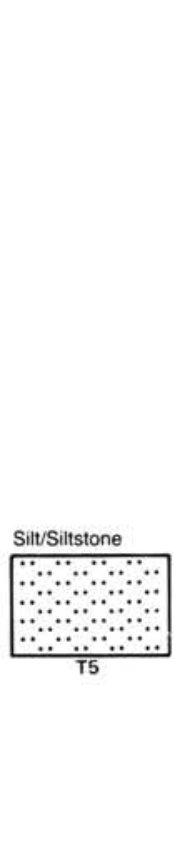

PELAGIC SEDIMENTS
Calcareous Biogenic Sediments

PELAGIC BIOGENIC CALCAREOUS - SOFT

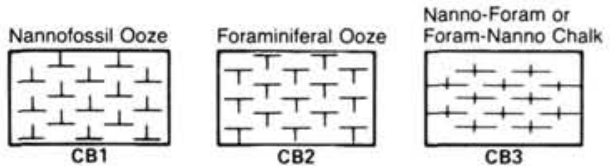

PELAGIC BIOGENIC CALCAREOUS - FIRM

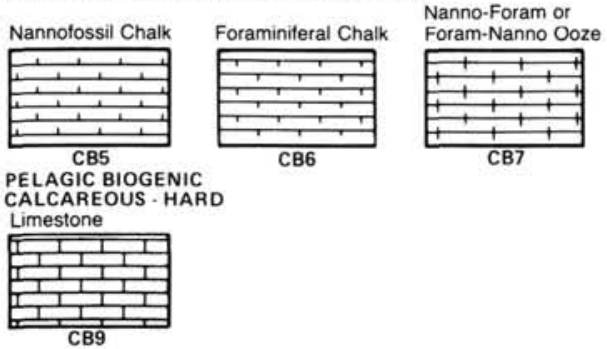

VOLCANOGENIC SEDIMENTS

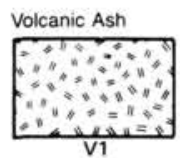

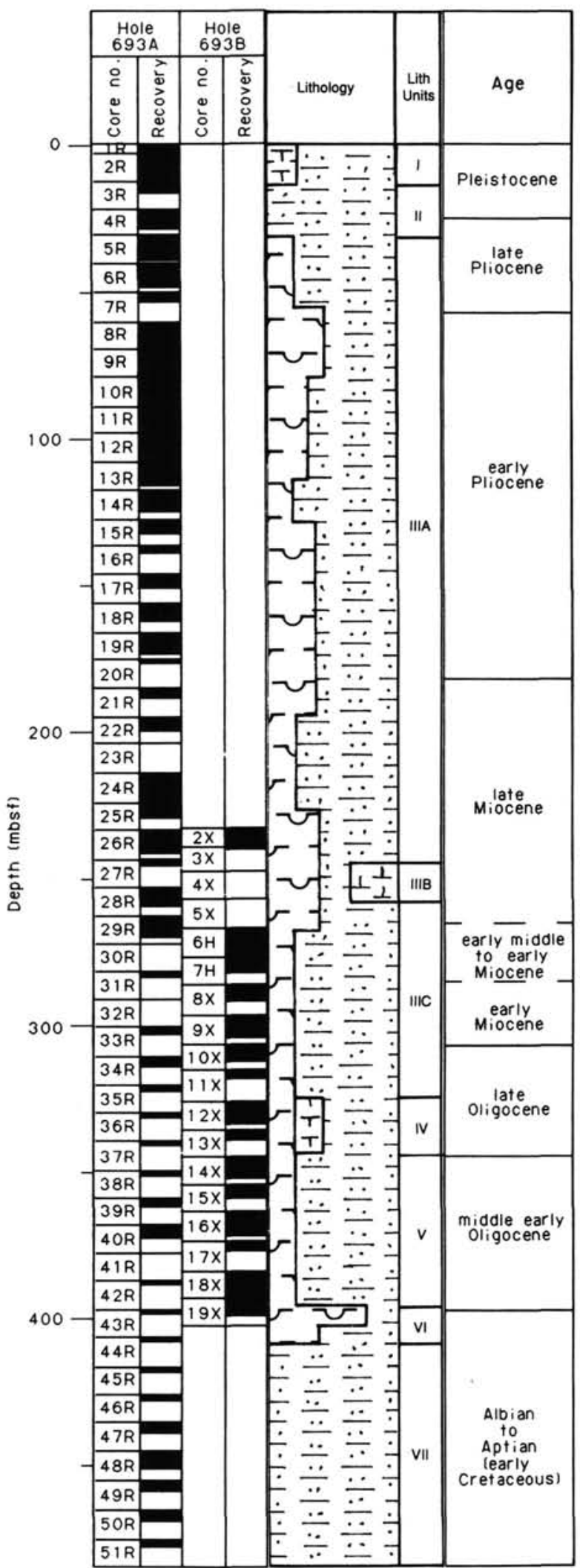

Figure 3. Generalized lithologic columns for Sites 693-697, based on sedimentary classification described in Shipboard Scientific Party (1988). A. Site 693. B. Site 694. C. Site 695. D. Site 696. E. Site 697; modified from Shipboard Scientific Party (1988). 

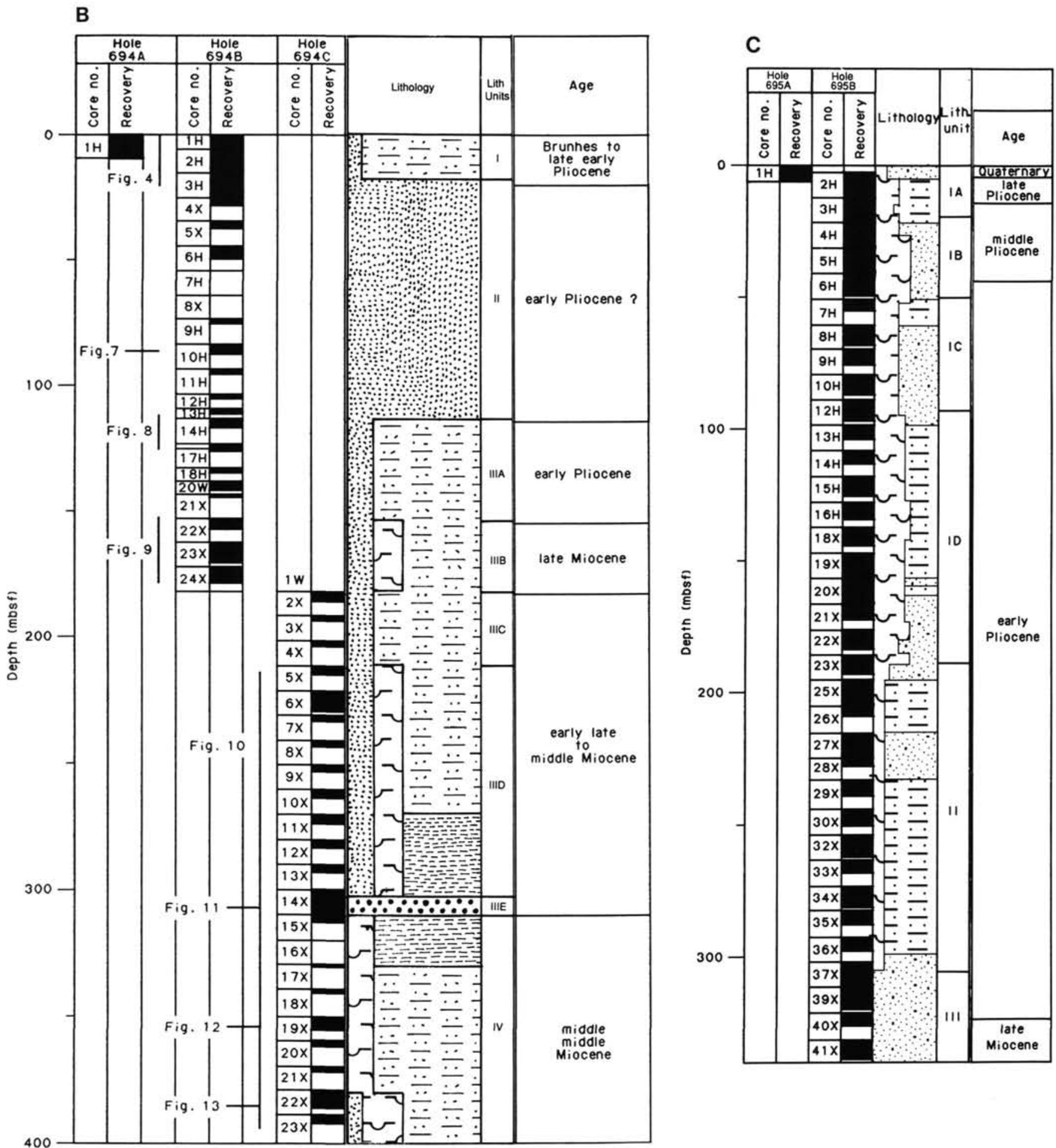

Figure 3 (continued).

board Scientific Party, 1988). Unit I (0.0-12.2 mbsf) consists of middle to upper Pleistocene foraminifer-bearing clayey mud. Unit II (12.2-31.4 mbsf) contains upper Pliocene to lower Pleistocene clayey mud. Unit III (31.4-325.8 mbsf) contains upper Oligocene to upper Pliocene diatom mud and silty to clayey diatom-bearing mud. This lithologic unit is divided into three subunits based on the variations in nannofossil and diatom content, with an 11.2-m-thick (243.9-255.1 mbsf) upper Miocene clayey diatom nannofossil ooze separating primarily clayey mud, diatom clayey mud, and silty and clayey diatom-bearing mud (Subunit IIIA) from clayey mud and silty mud (Subunit IIIC). Unit IV (325.8-345.1 mbsf) consists of interbedded upper Oligocene diatom mud and ooze, with minor muddy nannofossil ooze and nannofossil-bearing clayey mud. Unit V (345.1-397.8 mbsf) is dominated by middle lower Oligocene diatom silty mud and diatom clayey mud, with isolated occurrences of gravel and pebbles interpreted to be ice rafted. Lower in the unit, some beds show evidence of mass wasting. 
C. H. SMITH, S. B. O'CONNELL
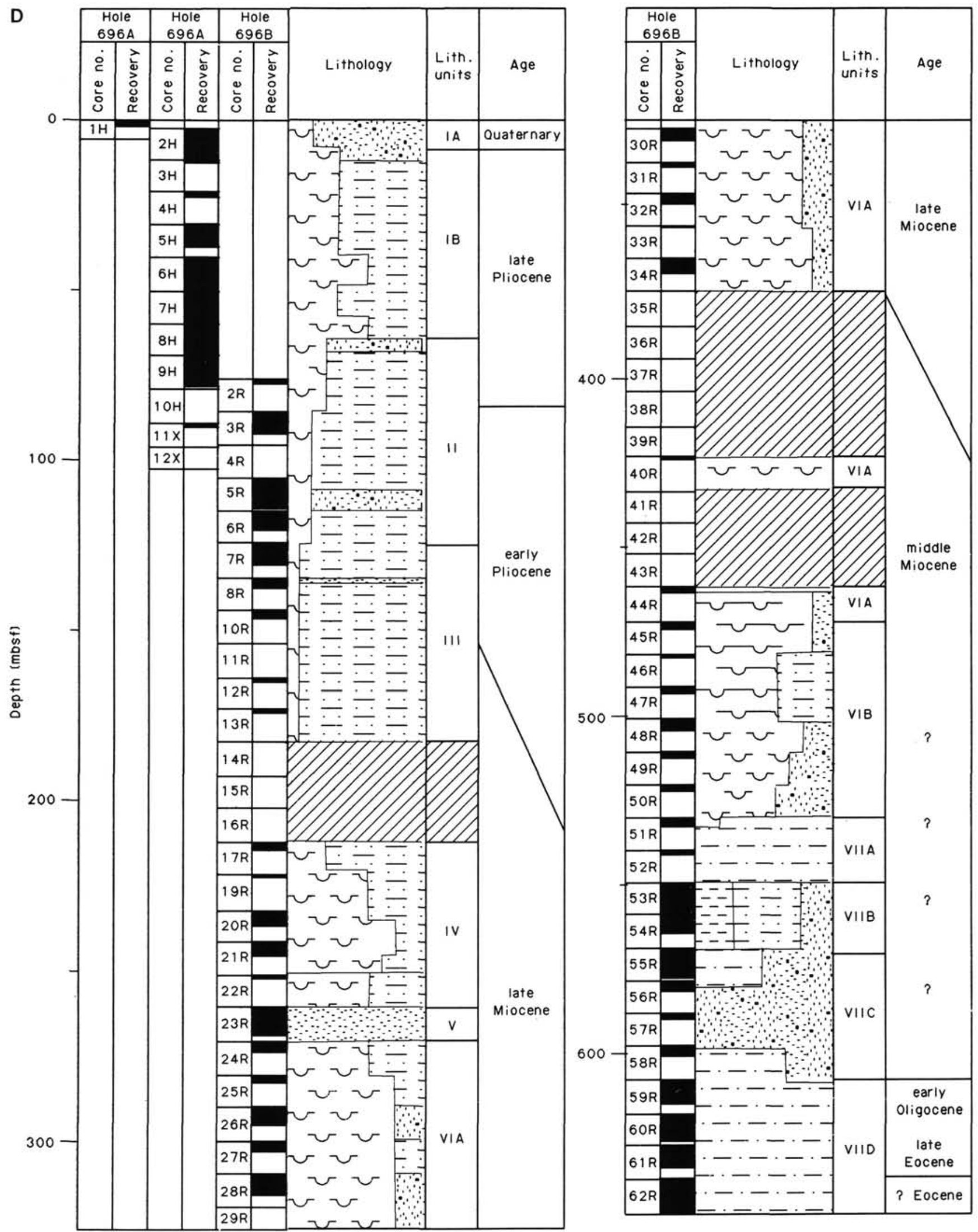

Figure 3 (continued). 
E

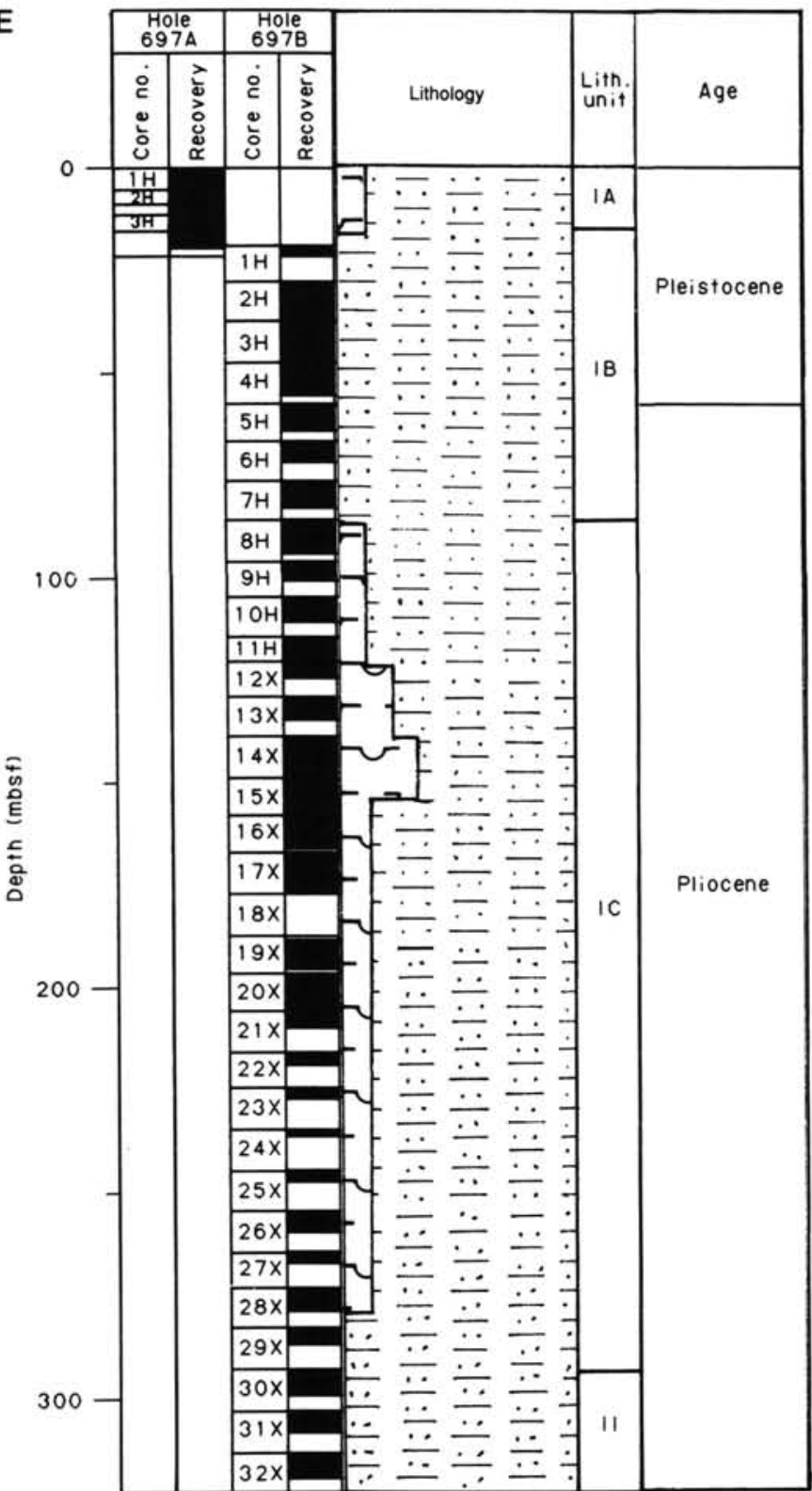

Figure 3 (continued).

Twenty-two samples taken between 0 and 380 mbsf were analyzed for sand size distribution during Leg 113 (Shipboard Scientific Party, 1988). The sand fraction falls into three groups: (1) Lower Oligocene sediments (380-345 mbsf) that contain a well-sorted very fine sand fraction with a few larger grains, (2) Upper Oligocene to upper Miocene sediments (345-200 mbsf) that contain a well-sorted very fine sand mode with a small, coarse tail, and (3) Upper Miocene to Pleistocene sediments (200-0 mbsf) that contain an unsorted sand fraction, with the largest grains commonly $2-3 \mathrm{~mm}$ in diameter. The transition between 1 and 2 is sharp, but the transition between 2 and 3 is gradual, extending over approximately $100 \mathrm{~m}$.

Site 694, in the Weddell Abyssal Plain, is dominated by terrigenous sediments with a minor biosiliceous component and ranges in age from middle middle Miocene to Pleistocene (Fig. 3B). Four lithologic units are defined. Unit I (0-21.1 mbsf), lower Pliocene to upper Pleistocene contains clay and clayey mud with minor amounts of silt, sand, and diatom-bearing clayey mud. Unit II (21.1-111.5 mbsf) consists predominantly of unconsolidated sand and was very poorly recovered $(16 \%)$. In general, the sediment fines upward from very coarse sand (311 mbsf) to sandy mud (189 mbsf). Unit III (111.5-304.3 mbsf) consists of a variety of middle Miocene to lowermost Pliocene hemipelagic and turbiditic sediments and has been divided into five subunits. Sediment types include graded silts, with and without diatoms; diatom-bearing silty and clayey muds with interbedded silts and sandy muds; and gravel-bearing sandy and silty muds.

Site 695 , on the southeast margin of the South Orkney Microcontinent (SOM), is the intermediate of three sites $(696,695$, and 697) that make up a vertical transect. Three lithologic units were identified, ranging in age from late Miocene to Quaternary (Fig. 3C). Unit I (0-190.0 mbsf) of Quaternary to early Pliocene age is composed of diatom-rich ooze (up to $80 \%$ diatoms) and silty, clayey mud. Unit II (190.0-306.9 mbsf) contains diatombearing silty and clayey mud of early Pliocene age, and Unit III (306.9-341.1 mbsf) consists of silty mud, with $0 \%-10 \%$ diatoms, of early Pliocene and probable latest Miocene age. Beds and laminae of volcanic ash are present throughout but are most common between 50 and 250 mbsf. Graded beds are rare and ice-rafted detritus occurs throughout, although it is most abundant above $20 \mathrm{mbsf}$ and in Unit II.

Site 696, the shallowest site drilled during Leg 113, is located in $650 \mathrm{~m}$ of water and lies on the southeastern margin of the SOM. Seven lithologic units were identified in the generally poorly recovered and commonly disturbed $645.6 \mathrm{~m}$ of sediment penetrated (Fig. 3D). Unit I (0-64.2 mbsf), is formed by Quaternary to lower upper Pliocene diatomaceous mud and ooze. Unit II (64.2-124.8 mbsf) consists of lower upper to lower Pliocene diatom-bearing silty and clayey mud. Unit III (124.8-211.8 mbsf) is composed of silty and clayey mud, with minor diatom-bearing clayey mud of early Pliocene to late Miocene age. Unit IV (211.8-260.1 mbsf) consists of upper Miocene diatom ooze and muddy diatom ooze, and Unit V (260.1-269.7 mbsf) is a turbiditic sand of late Miocene age. The upper part of Unit VI (269.7-529.8 mbsf) consists of a diatom ooze and mud-bearing diatom ooze underlain by diatomite and mud-bearing diatomite of late and middle Miocene age. Unit VII (529.8-645.6 mbsf) is dominated by Miocene to Eocene(?) terrigenous sediments and has been divided into four subunits; sandy mudstone (Subunit VIIA); claystone, clayey mudstone, and silty mudstone (Subunit VIIB); glauconitic silty mudstone and claystone (Subunit VIIC); and sandy mudstone (Subunit VIID). Ice-rafted detritus is common from the middle upper Miocene ( $366 \mathrm{mbsf}$ ) to the present, and in two intervals, 530 and 570 mbsf, in sediments of early Miocene and Oligocene age, respectively.

Site 697 , located in $3480 \mathrm{~m}$ water depth, lies in Jane Basin. Predominantly hemipelagic sediments were recovered and were divided into two lithologic units (Fig. 3E). Unit I (0-293.0 mbsf) consists of clayey and silty mud. The diatom content is variable, and diatoms are present both as laminae and disseminated in the mud. Three subunits are defined. Subunit IA (0-15.5 mbsf) is composed of upper Quaternary silty mud and diatom-bearing silty mud; Subunit IB (15.5-85.7 mbsf) is formed by upper Pliocene and Pleistocene clayey mud and clay and is almost devoid of diatoms; and Subunit IIB (85.7-293.0 mbsf) is dominated by Pliocene diatom-bearing clayey mud. Unit II (293.0-322.9 mbsf) consists of silty and clayey mud, of early Pliocene age, and is devoid of diatoms. Thin, altered, volcanic ash layers and icerafted detritus are present throughout, but the ice-rafted material is abundant only near the base of the sequence. Sedimentation rates at this site are more than five times higher than at any of the other Leg 113 sites. 


\section{METHODS}

\section{Samples and Sample Preparation}

The sample base for this study consists of 202 Oligocene to Pleistocene, $20 \mathrm{~cm}^{3}$ sediment samples from ODP Leg 113 Sites 693-697 (Fig. 1). Sample density is variable, which reflects core recovery and relative abundance of sand in the cores.

Shape measurements were restricted to quartz grains in the very fine sand fraction (63-125 $\mu \mathrm{m})$, thus minimizing shape variation that may be the result of compositional or widely ranging size variations (Griffiths, 1967). Very fine sand fraction samples for Fourier shape measurement were isolated by sieving and treated with $50 \% \mathrm{HCl}$ with the addition of stannous chloride and then $19 \% \mathrm{HF}$. This removed organic material, clays, iron stains, and etched or dissolved nonquartzose minerals. Hydrofluoric acid used at suggested time/concentration values does not appreciably affect the shape of quartz sand grains (Schultz, 1980).

The subset of samples selected for SEM study was first boiled in $50 \% \mathrm{HCl}$ to dissolve carbonate and organic material and run through a magnetic separator to remove magnetic minerals. Quartz grains were optically selected under a binocular microscope, mounted on adhesive-coated SEM stubs, and sputter coated with palladium gold approximately $90-150 \AA$ thick.

\section{Fourier Shape Analysis}

After sample preparation, a split of each very fine sand sample was mounted on a petrographic slide with glycerine, and 200 quartz grains were digitized on a microprocessor-controlled image analysis system (Mazzullo and Kennedy, 1985). In the Fourier technique, the two-dimensional shape of a digitized grain outline is quantitatively described by use of a Fourier series in closed form, which breaks down the digitized grain outline into n components of shape, called "harmonics" and measures the relative contribution, or "amplitude," of each of these components to the total sum outline. The amplitudes of the higher-order harmonics measure fine shape. Generally, the amplitudes for 23 harmonics (2-24) are measured for each grain and constitute the "harmonic amplitude spectrum" (Ehrlich and Weinberg, 1970).

To compare the large data sets generated, data are presented in the form of amplitude frequency distributions, which display the range of amplitude values at a given harmonic for each sample (Ehrlich et al., 1980). Each sample is thus represented by a series of 23 amplitude frequency distributions.

Vector analysis of the amplitude frequency distributions provides a useful tool for determining end-member populations in shape studies (Miesch, 1976; Hudson and Ehrlich, 1980). Differentiating end members was accomplished using the extended CABFAC Q-mode method (Klovan and Miesch, 1976; Miesch, 1976).

Some harmonics or shape spectrums show larger variation (contrasts)' between samples and thus contain more information about shape changes. The larger variation is interpreted to provide more information about provenance history than other harmonics. Identifying these information-rich portions of the data set was determined by the "relative entropy" method described by Full et al. (1984). Relative entropy is defined as the ratio of the calculated sample entropy and the maximum possible entropy. The harmonics with the lowest relative entropy values contain the greatest intersample variability and the highest potential for a clear solution by vector analysis or other pattern recognition algorithms. Vector analysis is used to define end members. At a later stage, samples with a high proportion of an end member were subjected to SEM inspection to relate the shape spectrum to geologic causes.

\section{RESULTS OF GRAIN SHAPE ANALYSES}

\section{Data Analysis}

A plot of the relative entropy values for each harmonic of the Fourier series (Fig. 4) shows that significantly low relative entropy values (i.e., high intersample variability) occur at harmonic 2 (which measures grain elongation) and harmonics 18 , 19,22 , and 23 (which measure various aspects of grain roundness). Q-mode vector analyses of the amplitude frequency distribution of the higher-order harmonics $(18,19,22$, and 23) were then conducted to distinguish different classes of sediments on the basis of quartz-grain roundness. This was not done for harmonic 2 since it is only a measure of grain elongation. Haines and Mazzullo (1988) found that grain elongation is not as useful as grain roundness in differentiating sediments from different source areas.

In the course of vector analyses, eigenvalues and communalities were examined to determine the number of end members that existed in the sample set and the degree to which models with increasing factors would succeed in reproducing the original normalized data. For higher-order harmonics $(18,19,22$, and 23), a three end-member solution explains greater than $94 \%$ of the variability in the normalized data matrices; i.e., the samples are mixtures in various proportions of three end members. The amplitude frequency distributions of the three end members for harmonics 18, 19, 22, and 23 are shown in Figure 5, and their sample designations are listed in Table 1.

End member 1 has simple unimodal amplitude frequency distributions that are skewed to the right, or high-amplitude, side of the histograms; it has high mean and modal amplitude values for all four harmonics; and mean 19th harmonic amplitude and Krumbein Roundness (KR) values of 0.006806 and 0.026 , respectively (Figs. 5,6 , and Table 2 ). Thus end member 1 is a population with a large number of relatively angular grains, and is referred to as the "angular end member."

End member 3 also has amplitude frequency distributions that are unimodal but slightly skewed to the left, or low-amplitude, side of the histogram (Fig. 5). It has low mean and modal amplitudes for all harmonics, and mean 19th harmonic amplitude and KR values of 0.0037663 and 0.425 , respectively (Table 2 ). Thus end member 3 is a population with a large number of relatively subrounded to rounded grains and is called the "rounded end member."

End member 2 has more complex polymodal amplitude frequency distributions (Fig. 5). It has intermediate mean and modal amplitude values for all harmonics and mean 19th harmonic amplitude and KR values of 0.0040558 and 0.388 , respectively (Table 2). Thus end member 2 is characterized by a population that is neither as angular nor as rounded as end members 1 and 3. This end member is termed the "intermediate end member."

\section{Identification of End Members}

Although a three end-member solution is considered satisfactory on the basis of the cumulative variance data, the actual validity of a three end-member solution can be evaluated only by considering its geologic plausibility. This evaluation was conducted by examining samples containing high percentages of the three end members with an SEM and determining whether the three end members actually represent samples of different provenances. Representative samples are shown in Plates 1-3.

Samples predicted on the basis of Fourier analysis to have a high percentage of the angular grains (end member 1) do contain a large proportion of grains that are angular and irregular in outline and form when examined under the SEM. The quartz grains typically have $>25 \%$ of both large- and small-scale conchoidal fractures (Pl. 1, Figs. 1-4), which are smoothly curved 

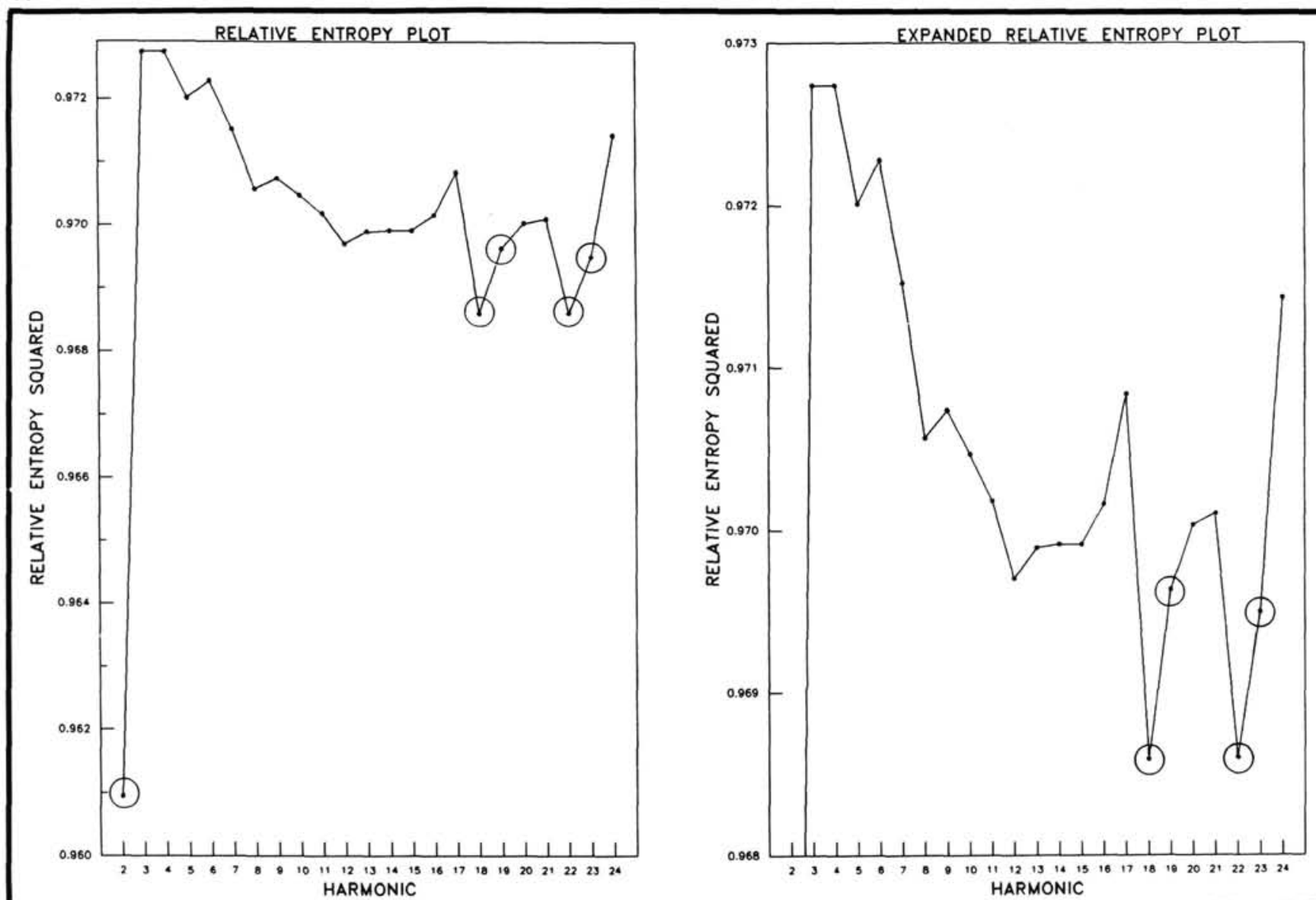

Figure 4. Relative entropy plots for samples from the Weddell Sea, Antarctica. Harmonics 2, 18, 19, 22, and 23 have the lowest relative entropy values and thus exhibit the greatest amount of intersample variability (from Smith, 1988). A. Relative entropy squared values for all harmonics, ranging from 0.960 to 0.973 . B. Relative entropy squared values ranging from 0.968 to 0.973 to show relationship between harmonics $18,19,22$, and 23 in expanded form.

surfaces with scalloped edges. A higher percentage $(>30 \%)$ of the grains have microblocks, which are 5- to $15-\mu \mathrm{m}$-long angular blocks of fragmented quartz, and microfractures $(>30 \%)$, which are subparallel and subplanar deformation sheets that are commonly superimposed upon larger scale blocks (PI. 1, Fig. 2). In addition, other small-scale features that are present and indicative of breakage are common to the grains, including comminution debris (Pl. 1, Fig. 2) and arc-shaped and semi-parallel steps (Pl. 1, Fig. 3). Lastly, a few grains $(<10 \%)$ have upturned plates that appear to have been formed subsequent to fracturing (PI. 1, Fig. 3).

These surface textures are characteristic of grains that are derived from crystalline rocks and crystalline rocks transported through glacial and glacial-marine regimes (Krinsley and Takahashi, 1962; Krinsley et al., 1964; Krinsley and Funnell, 1965; Krinsley and Donahue, 1968; Krinsley and Margolis, 1969; Margolis and Kennett, 1970; 1971; Mazzullo and Magenheimer, 1987; Ritter, 1987). Quartz grains that are released from crystallinerock sources commonly contain large numbers of fractured grains (e.g., Mazzullo and Magenheimer, 1987; Haines and Mazzullo, 1988), and even nonfractured crystalline grains contain one or more sets of partly healed fractures (Moss and Green, 1975). Ritter (1987) has shown that when such quartz grains are supplied to a glacial transport system, weathering and abrasion continue the fracturing process of the already fractured grains (producing microblocks and comminution debris) and reopens the partly healed fractures of the nonfractured grains. The abundance of fractures on crystalline glacial grains, visible by SEM, is the only feature that is distinctive from crystalline nonglacial quartz grains (Dowdeswell et al., 1985; Ritter, 1987).

The probable source of the angular end-member grains is crystalline rocks fractured upon formation or deformation, and crystalline rocks exposed to erosion and weathering by ice. These sediments were transported to the marine environment through glacial mechanisms (e.g., glacial outwash, ice-rafted debris) or from local crystalline sources that were fractured during formation or deformation.

Samples with high percentages of the intermediate end member contain abundant subangular and irregular grains, and the predominant surface textures on these grains are crystalline nodes, grain embayments, and fractures (Pl. 2, Figs. 1-4). Crystalline nodes are anhedral and subhedral protuberances with flat or slightly curved growth interference faces separated by angular edges (Pl. 2, Figs. 1-4); grain embayments are shallow, wide depressions impressed upon the quartz grain by adjacent, previously crystallized mineral phases (Pl. 2, Figs. 1-4; Mazzullo and Magenheimer, 1987). The intermediate end-member grains are all characterized by large-scale reentrants and bulges that are 5$50 \mu \mathrm{m}$ in size; the fractures include small-scale $(5-10 \mu \mathrm{m})$ conchoidal fractures. These surface textures suggest first-cycle quartz grains that were derived from local outcrops of crystalline rocks 


\section{SHAPE FREQUENCY DISTRIBUTIONS}

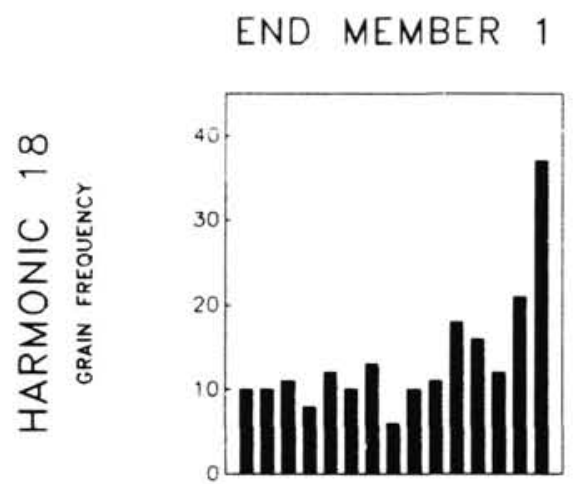

END MEMBER 2
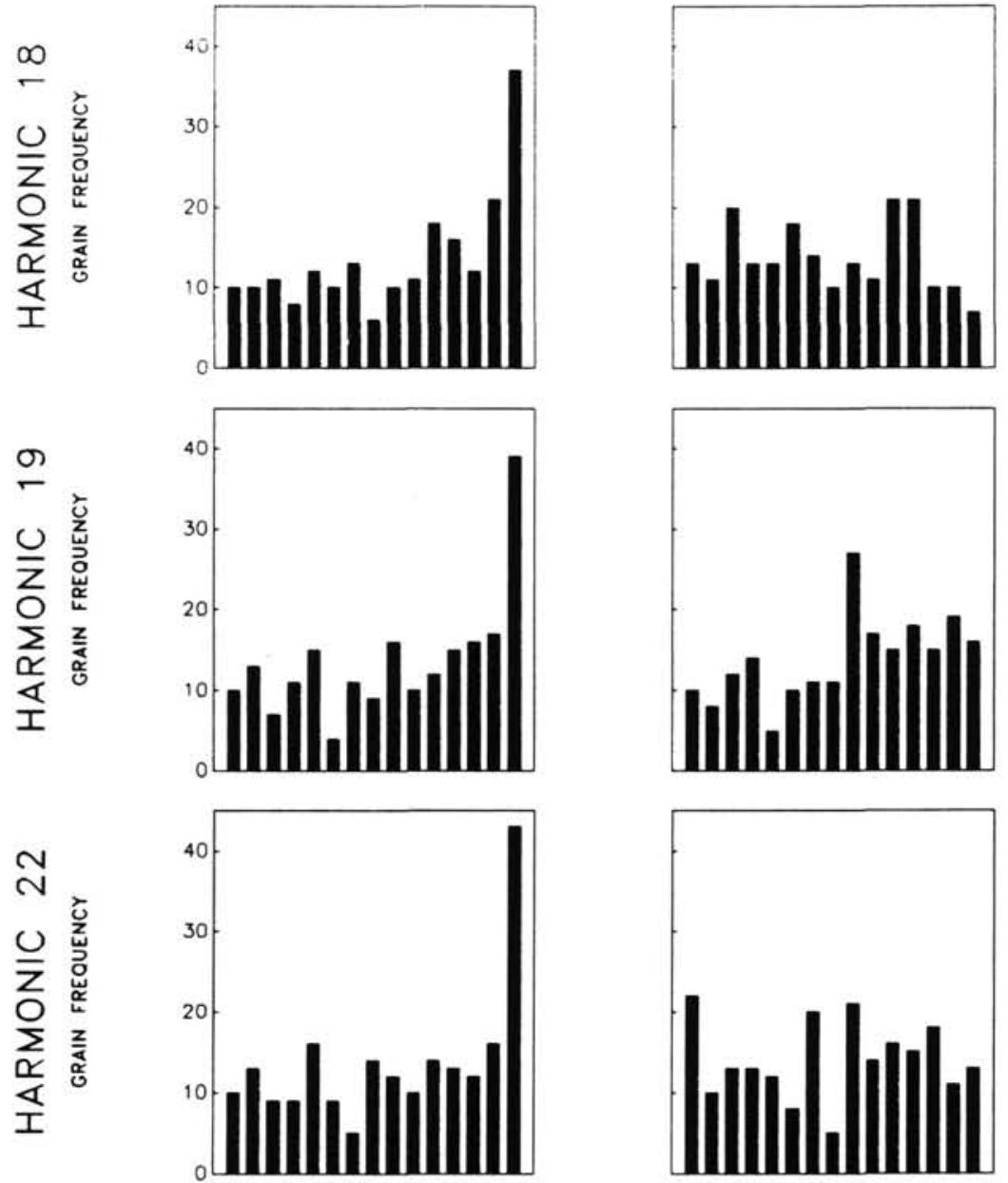

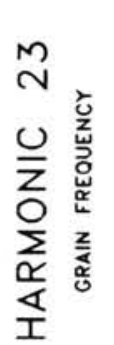
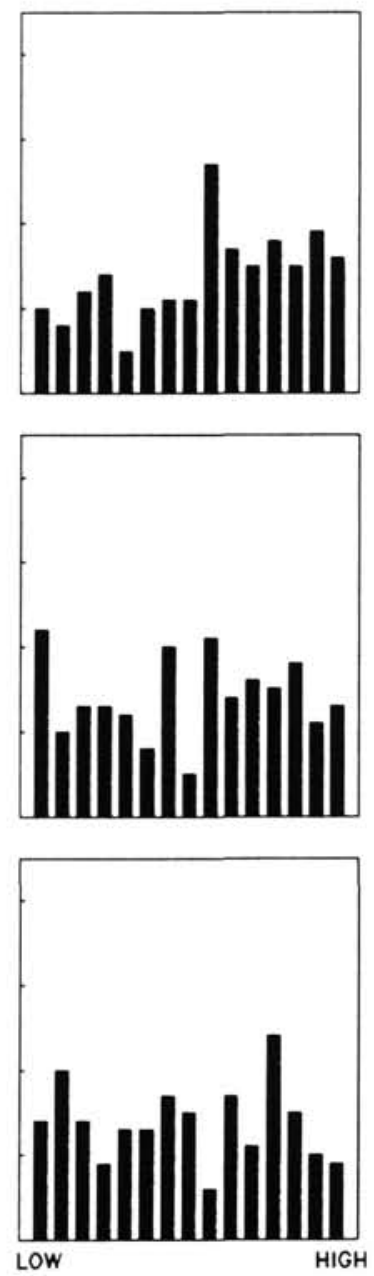

AMPLITUDE

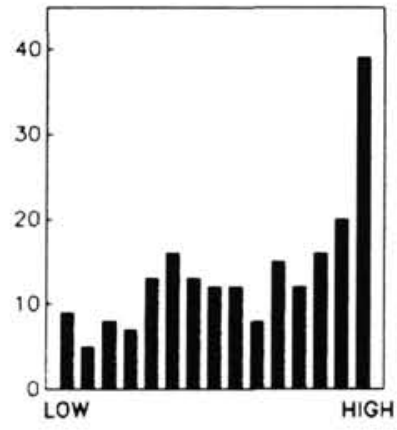

AMPLITUDE
END MEMBER 3
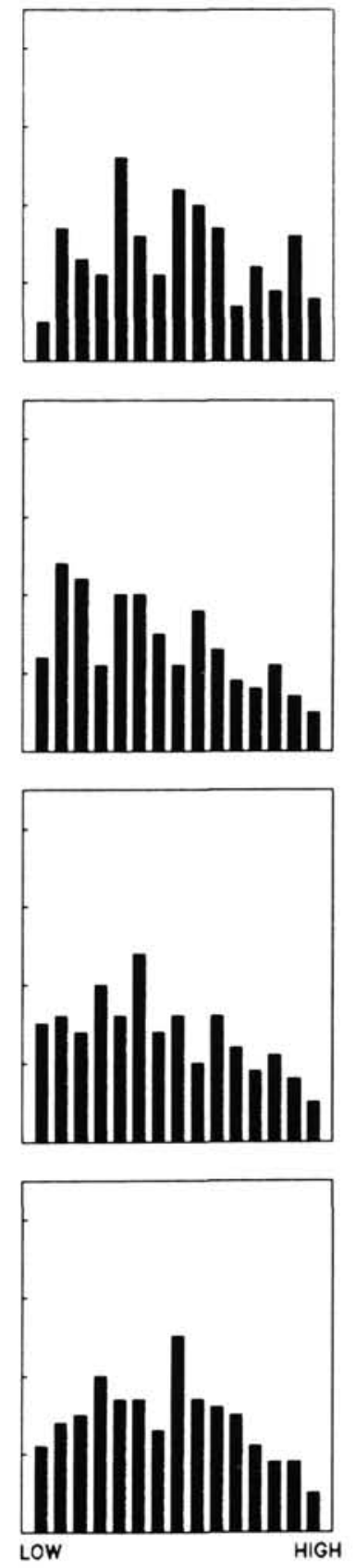

AMPLITUDE

Figure 5. End member shape frequency distributions for harmonics 18, 19, 22, and 23 (from Smith, 1988).

and were not subjected to abrasion and fracturing in glacial environments (Mazzullo and Magenheimer, 1987; Ritter, 1987).

At Site 693 on the East Antarctic margin, these first-cycle quartz grains may have been derived from felsic intrusives that crop out in the Ahlmann Ridge or the Paleozoic quartzites in the Kirwan Escarpment (Fig. 1). This conclusion is corroborated by Andrews (1984), who, on the basis of analyses of pis- ton core samples, determined that the petrologic province near Site 693 on the East Antarctic margin is dominated by tholeiitic basalts, andesites, and gray quartzites with quartz arenites and quartz wackes occurring in limited amounts. In addition, Hamilton (1965) found a similar mineral assemblage in sediments dredged from Halley Bay and suggested that they may have originated in the Shackleton Range of East Antarctica. Poten- 
Table 1. End members and their corresponding sample designation. Sample designation given as Hole-Core-SectionInterval (cm). Numbers in parentheses refer to sample depth (mbsf).

\begin{tabular}{lllll}
\hline \multicolumn{1}{c}{ Harmonics } & \multicolumn{1}{c}{18} & \multicolumn{2}{c}{19} & 22 \\
\hline End member & & & & \\
1 (rounded) & $694 \mathrm{C}-05 \mathrm{X}-02-01(210.41)$ & $693 \mathrm{~A}-13 \mathrm{R}-02-80(110.90)$ & $693 \mathrm{~A}-13 \mathrm{R}-02-80(110.90)$ & $695 \mathrm{~A}-21 \mathrm{X}-02-07(169.37)$ \\
2 (intermediate) & $697 \mathrm{~B}-12 \mathrm{X}-01-59(120.39)$ & $696 \mathrm{~B}-53 \mathrm{R}-02-80(551.20)$ & $695 \mathrm{~A}-30 \mathrm{X}-03-110(248.50)$ & $695 \mathrm{~A}-05 \mathrm{H}-02-108(34.18)$ \\
3 (angular) & $694 \mathrm{~B}-24 \mathrm{X}-02-108(172.18)$ & $694 \mathrm{~B}-24 \mathrm{X}-02-108(172.18)$ & $694 \mathrm{~B}-24 \mathrm{X}-02-108(172.18)$ & $694 \mathrm{~B}-24 \mathrm{X}-02-108(172.18)$ \\
\hline
\end{tabular}

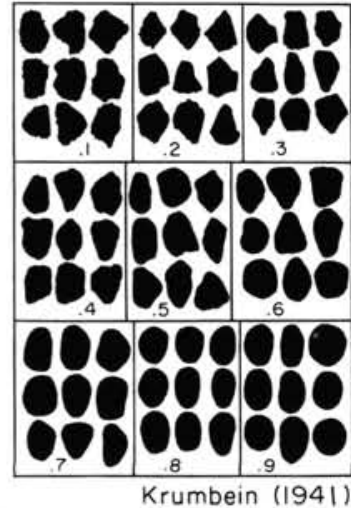

A

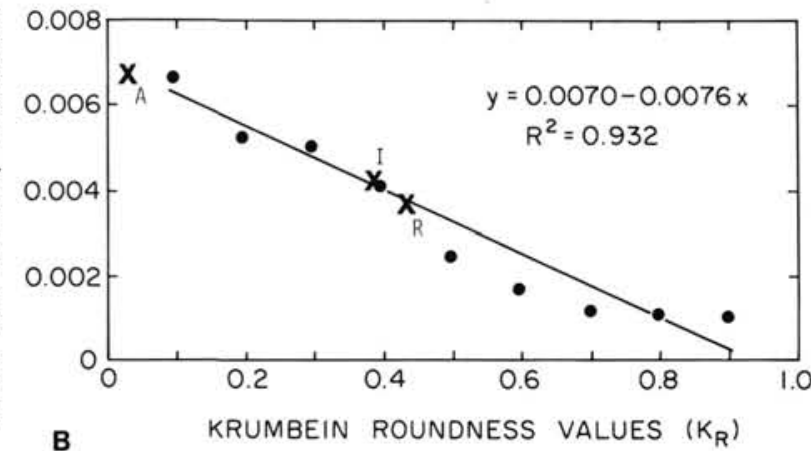

Figure 6. A. Pictorial depiction of Krumbein roundness (1941) scale with assigned numeric designation. B. Mean amplitudes of harmonic 19 plotted against each grain outline roundness class in the Krumbein (1941) comparator scales. Generally the mean amplitude for harmonic 19 decreases with increasing roundness (modified from Haines and Mazzullo, 1988). Also shown (x's) are the mean harmonic 19 and Krumbein roundness values for each of the three end-member classes identified in this study; $\mathrm{A}=$ angular, $\mathrm{I}=$ intermediate, and $\mathrm{R}=$ rounded. tial crystalline source rocks adjacent to Sites 695,696 , and 697 are the Coronation Metamorphic complex, which forms the basement of the South Orkney Islands, and the Andean Intrusive Suite to the south. Edwards and Goodell (1969) describe a metamorphic petrologic suite in the sediments of the South Orkney margin region that was derived from the southern coast of the Weddell Sea.

Examination of surface textures of the rounded end member shows that a high percentage of grains is round to subrounded and exhibits both chemical and mechanical surface features. The chemical surface textures include irregular precipitation and dissolution topography, silica dissolution features, flat or hummocky sheets of amorphous silica, and caps of amorphous silica (Pl. 3, Figs. 1-4). The sheets and caps of amorphous silica give the grains a smooth appearance and round the edges of the grain (Pl. 3, Figs. 1, 4). Precipitation and dissolution of silica gives the grain surfaces an overall rough appearance (Pl. 3, Figs. $2,3)$. Mechanical surface textures include worn and evidently abraded surfaces and edges (Pl. 3, Figs. 1,4). The rounded end member quartz grains are interpreted to be multicyclic sedimentary grains with surface textures that were inherited from their original sources. The surface textures are indicative of weathering in a terrestrial environment and abrasion in eolian environments. However, it is probable that the weathering and abrasion did not occur during the most recent cycle of sedimentation, because not all of the grains show these surface textures.

The sources of these grains at Site 693 are postulated to be the Precambrian sediments that crop out in the Ahlmann Ridge, the Paleozoic and Mesozoic sedimentary rocks of the Kirwan Escarpment, and the sedimentary rocks of the Jurassic Beacon Supergroup, which is exposed in the Heimefront Range (Fig. 1). Andrews (1984) concluded that the sediments near Site 693 were characterized by lithologies of tholeiitic basalts, andesites, and gray quartzite, with limited quartz arenites and wackes, derived from the Paleozoic and Mesozoic Beacon Basin. The sources of multicyclic grains for Sites 695,696 , and 697 are presumably the sedimentary formations on the South Orkney Islands and the sedimentary rocks of the Northern Antarctic Peninsula (Fig. 6).

In summary, the angular end member grains are interpreted to be derived from crystalline rocks and/or glacially transported.

Table 2. Correlation of harmonic 19 mean amplitude values to Krumbein roundness (KR) values for end member samples. Sample designation given as Hole-Core-Section-Interval (cm).

\begin{tabular}{llrcc}
\hline $\begin{array}{c}\text { End } \\
\text { member }\end{array}$ & \multicolumn{1}{c}{ Sample } & $\begin{array}{c}\text { Depth } \\
(\mathrm{mbsf})\end{array}$ & $\begin{array}{c}\text { Harmonic 19 } \\
\text { mean amplitude }\end{array}$ & $\begin{array}{c}\text { Krumbein } \\
\text { roundness (KR) }\end{array}$ \\
\hline Rounded & 694C-05X-02-01 & 210.41 & 0.004184 & 0.370 \\
Rounded & 695A-21X-02-107 & 169.37 & 0.003739 & 0.429 \\
Rounded & 693A-13R-02-80 & 110.90 & 0.003376 & 0.477 \\
Intermediate & 697B-12X-01-59 & 120.39 & 0.003824 & 0.418 \\
Intermediate & 696B-53R-02-80 & 551.20 & 0.004665 & 0.307 \\
Intermediate & 695A-30X-03-110 & 248.50 & 0.004069 & 0.386 \\
Intermediate & 695A-05H-02-108 & 34.18 & 0.003665 & 0.439 \\
Angular & 694B-24X-02-108 & 172.18 & 0.006806 & 0.026 \\
\hline
\end{tabular}


The intermediate end member grains are interpreted to have a crystalline (first-cycle) origin without abrasion and fracturing in a glacial environment. The rounded end member grains are interpreted to have a sedimentary (multicyclic) origin.

\section{Vertical Distribution of End Members}

Normalized composition loadings that are proportional to the relative percentage of each end member in a sample were averaged over the higher order harmonics $(18,19,22$, and 23$)$ for each of the three end members for each sample. These average proportions were then plotted against depth in the Hole (Figs. 7, 8, and 9; Appendix). The observed changes in the relative percentage are described from bottom to top of each site investigated.

\section{Site 693}

Site 693 shows large and complex variations in the relative percentages of the three end members (Figs. 7-9; Appendix, Table 1). With the exception of one lower middle Miocene sample, the general trend from the lower Oligocene to the upper Miocene is a small, general decrease in the percentage of the angular end member (Fig. 7), with averages ranging as follows: (1) lower
Oligocene, $22 \%-43 \%$, (2) upper Oligocene, $11 \%-26 \%$, (3) lower to middle Miocene, $15 \%-48 \%$, and (4) upper Miocene, $6 \%$ $31 \%$. In the lower Pliocene sediments, where the highest density of samples was analyzed, the percentage of angular end members is highly variable but does show a general upward increase. The highest proportion of angular grains $(61 \%)$ lies at the lower/upper Pliocene boundary. No Pleistocene samples were analyzed.

The rounded end member generally follows a pattern opposite to the angular end member (Fig. 8), with proportions that vary as follows: (1) lower Oligocene, $20 \%-45 \%$, (2) upper Oligocene $34 \%-54 \%$, (3) lower to middle Miocene, $24 \%-50 \%$, and (4) upper Miocene, $24 \%-55 \%$. The proportion of intermediate (crystalline) end members varies over a small range (Fig. 9), being relatively stable in the lower Oligocene to middle Miocene sediments and then fluctuating slightly in the upper Miocene to upper Pliocene.

\section{Site 694}

At Site 694 the patterns of variation in the proportions of angular and rounded end members show a roughly inverse correlation in the Miocene and Pleistocene but not in the Pliocene

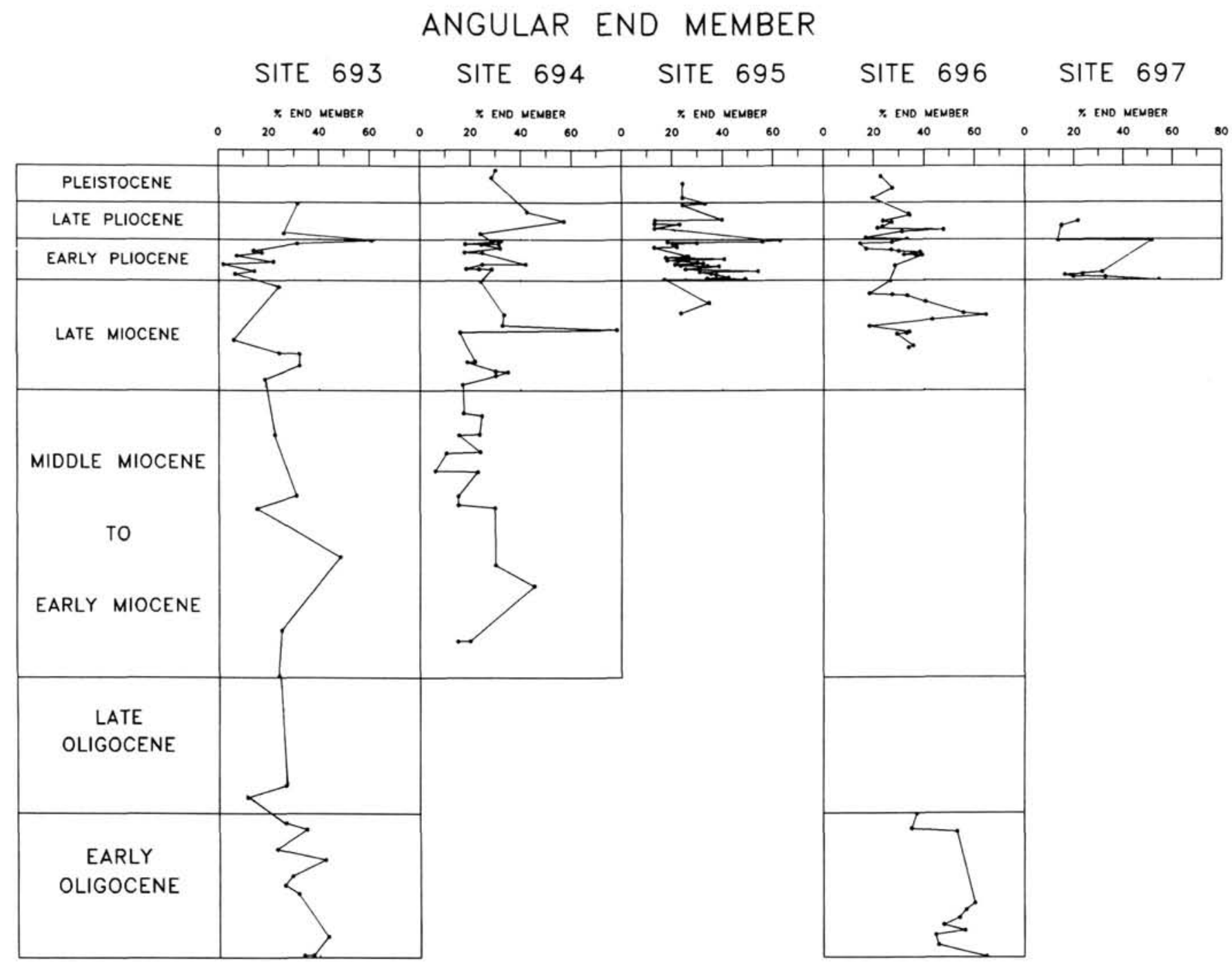

Figure 7. Variation in the abundance in each sample of the "angular end member" for Sites 693-697, plotted against its depth in the hole and age based on diatoms and magnetostratigraphy (from Smith, 1988). 


\section{ROUND END MEMBER}

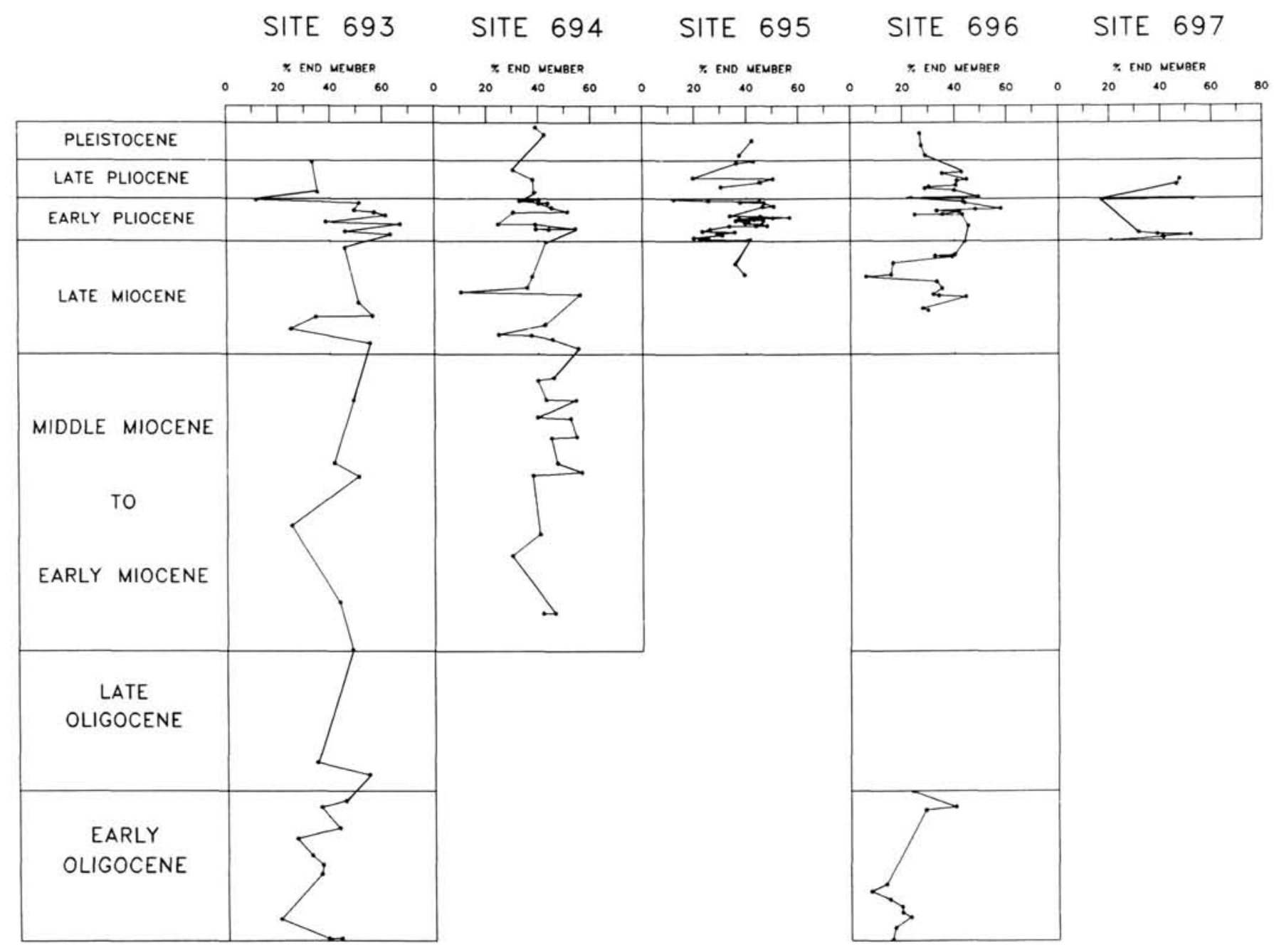

Figure 8. Variation in the abundance in each sample of the "rounded end member" for Sites 693-697, plotted against its depth in the hole and age based on diatoms and magnetostratigraphy (from Smith, 1988).

(Figs. 7, 8; Appendix, Table 2). The proportion of the intermediate end member shows no systematic downhole trend (Fig. 9).

After an initial increase $(15 \%-45 \%)$ in the lower Miocene, the distribution of the angular end member shows a slight but variable decrease in the middle Miocene, with values ranging from $24 \%$ to $6 \%$. In the upper Miocene, values continue to remain generally low, with the exception of a large increase, to $79 \%$, in the middle upper Miocene. In the lower Pliocene, the angular proportion fluctuates between $17 \%$ and $41 \%$, with no systematic trend. Only three upper Pliocene samples were analyzed. Values range from $23 \%$ to $56 \%$, with the highest percentage of the angular member in the middle upper Pliocene. Both Pleistocene values were about $30 \%$.

In the lower and middle Miocene section the proportion of the rounded end member ranges between $29 \%$ and $56 \%$ without a systematic trend. Two decreases, one very abrupt and one more gradual, are observed in the upper Miocene. The rounded end member proportions fluctuate during the lower Pliocene with two high peaks $(51 \%$ and $54 \%)$. During the Pleistocene and upper Pliocene values range between $30 \%$ and $42 \%$.

At Site 694 the intermediate end member fluctuates between $30 \%$ and $43 \%$ in the middle and lower Miocene and in the up- per Miocene section between $11 \%$ and a high of $45 \%$. The percentage of the intermediate member fluctuates between $23 \%$ and $45 \%$ in the lower Pliocene and shows an inverse correlation to the angular end member in the upper Pliocene.

\section{Site 695}

At Site 695, where the highest overall sample density was available, there is again an inverse relationship between the proportions of the rounded and angular end members (Figs. 7, 8; Appendix, Table 3). There is a fluctuating but systematic decrease in the percentage of angular grains in the lower Pliocene, with values ranging between $55 \%$ and $12 \%$. Upper Pliocene values, although variable with two high peaks, one at the upper/ lower Pliocene boundary $(63 \%)$ and the other in about the middle of the upper Pliocene (39\%), do not show any major systematic trends. Both Pleistocene values were about $24 \%$.

Lower Pliocene values for the rounded end member range between $22 \%$ and $56 \%$, with a general increase until just below the lower/upper Pliocene boundary, where the proportion of the rounded end member is $11 \%$. In the upper Pliocene, values range from $19 \%$ to $50 \%$, showing trends that are the inverse to those observed in the angular grains. 


\section{INTERMEDIATE END MEMBER}

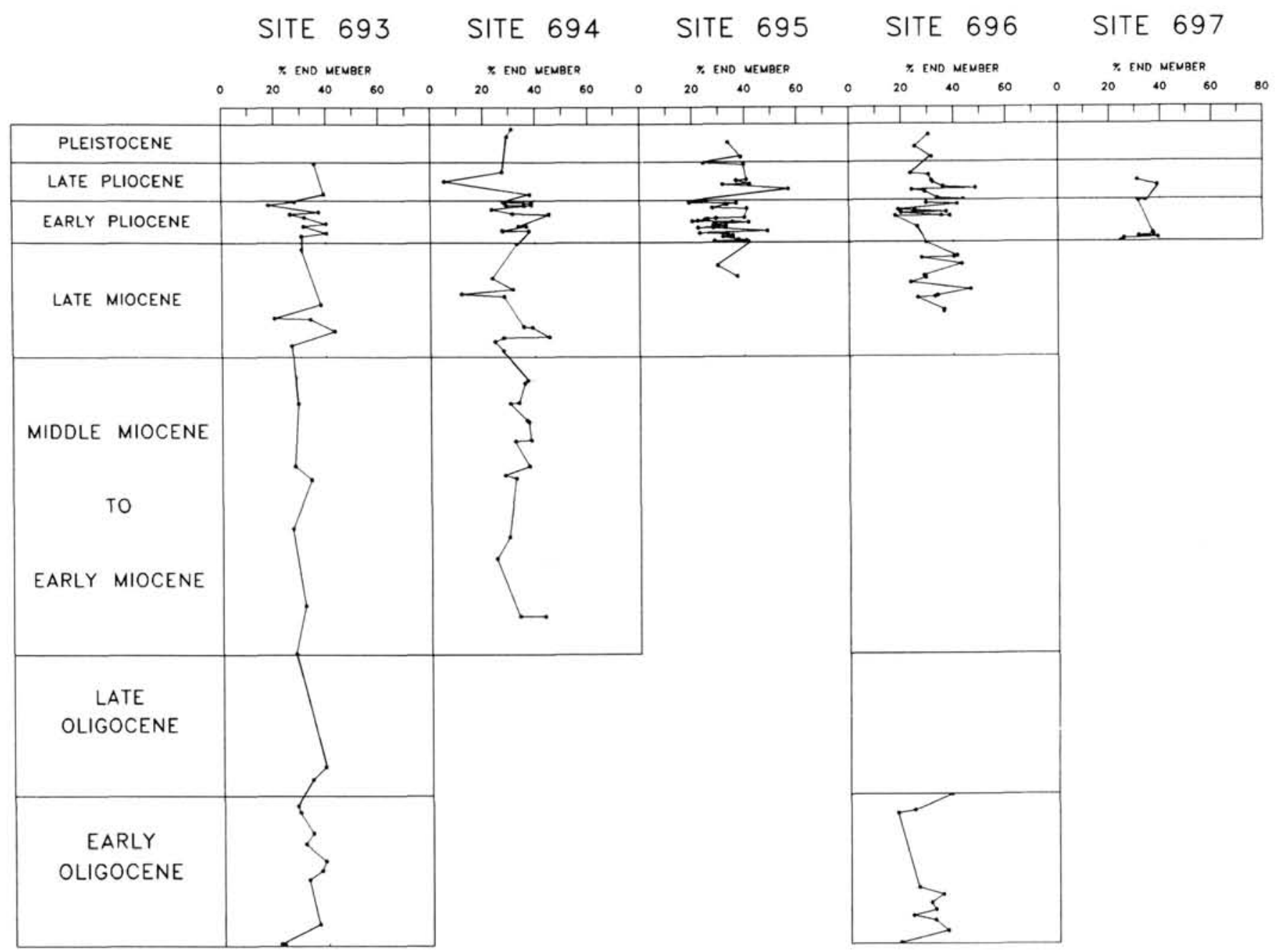

Figure 9. Variation in the abundance in each sample of the "intermediate end member" for Sites 693-697, plotted against its depth in the hole and age based on diatoms and magnetostratigraphy (from Smith, 1988).

The intermediate end member has large fluctuations in the lower Pliocene ranging between $19 \%$ and $48 \%$. In the upper Pliocene, fluctuations range between $24 \%$ and $56 \%$.

\section{Site 696}

Site 696 sediment samples show complex and varying proportions of end members (Figs. 7 through 9; Appendix, Table 4). The most surprising result is in the lower Oligocene samples, which show the highest proportion of angular grains of any time interval sampled $(35 \%-64 \%)$. Pollen samples from these sediments indicate that the South Orkney Microcontinent was experiencing temperate climatic conditions during this time (Shipboard Scientific Party, 1988). Additional sand samples were not recovered until the upper Miocene, where two trends of decreasing angularity were observed. Only two samples were available for the lower Pliocene, but the upper lower Pliocene shows a steady decrease in angularity, with fluctuations at the lower/upper Pliocene boundary. These fluctuations continue into the upper Pliocene and Pleistocene without showing any systematic trend.

Both the rounded and intermediate end members at Site 696 primarily show trends which are the reverse of the angular end member. This includes relatively low values for samples from the lower Oligocene.

\section{Site 697}

The Site 697 sediment samples again show a directly inverse correlation between the angular and rounded end members (Figs. 7, 8; Appendix, Table 5). As the sediments were generally fine grained, only 10 samples were analyzed. The highest proportions of angular grains are present at the Miocene/Pliocene and lower/upper Pliocene boundaries. In both instances, these high values are followed by a decrease in the percentage of angular grains, a decrease which is much more pronounced in the upper Pliocene. No Pleistocene samples were available. The intermediate member values vary by about $20 \%$.

\section{Areal Distribution of End Members}

Although there is no strong dominance, in general, the rounded end member grains are more predominant on the East Antarctic margin (Site 693) and the central basin (Site 694) than on the western margin of the Weddell Sea (Sites 695, 696, and 697). The intermediate end member grains are present in relatively equal proportions at all sites, averaging $30 \%-31 \%$. As the per- 
centages of the different end members fluctuate upsection, no consistent change is seen throughout the sites at any one time. This is true even for the South Orkney sites, although Sites 695 and 697 both show high angular and low rounded percentages at the Pliocene/Miocene and upper/lower Pliocene boundaries.

The western, more northerly sites $(695,696$, and 697$)$ have a slightly larger angular end member component than do the eastern (Site 693) and central basin (Site 694) sites, although the average of the areal distribution is similar for all sites. The distribution of angular grains is as follows: (1) Holes 693A and 693B average $24 \%$ and range between $1 \%$ and $48 \%$; (2) Holes 694B and $694 \mathrm{C}$ average $24 \%$ and range between $15 \%$ and $56 \%$; (3) Hole $695 \mathrm{~A}$ has an average of $27 \%$, ranging between $16 \%$ and $54 \%$; (4) Holes 696A and 696B average $35 \%$ and range from $14 \%$ to $60 \%$; and (5) Site 697 averages $27 \%$, ranging from $13 \%$ to $54 \%$.

\section{Identification of Shape Significance}

To evaluate the downhole changes in the proportions of the three end members, several techniques were applied to evaluate shape differences between samples. The mean harmonic 19 was plotted against mean harmonic 2 (sphericity) to quantify differences in sphericity between samples and holes. With the exception of Samples 113-693-39R-2, 79-83 cm; 113-694B-2H-3, 111$113 \mathrm{~cm}$; 113-694B-2H-2, 71-73 cm; 113-694B-24X-2, 108-112 $\mathrm{cm}$; 113-695A-7H-3, 4-8 cm; and 113-697B-32X-4, 98-100 cm, the quartz grains do not generally differ in sphericity. With the exception of these samples, sphericity cannot be used to differentiate grain shape groupings in the Weddell Sea region.

For all samples and for each hole, proportions of the three end members were plotted on ternary diagrams to determine if any shape significance was evident. The proportional variations were homogeneous, and distinct shape differences between Site 693, and Sites 695, 696, and 697 could not be identified.

\section{DISCUSSION}

\section{Identification of Local Sources}

Three types of very fine quartz sand have been identified in the Weddell Sea sediments; (1) angular (end member 1), crystalline grains, fractured upon formation or deformation and crystalline grains exposed to weathering or transport by ice; (2) intermediate (end member 2), first-cycle crystalline rocks derived from felsic intrusives and Lower Paleozoic quartzites of East Antarctica, the Andean Intrusive Suite, and the South Orkney metamorphics of West Antarctica; and (3) rounded (end member 3), multicyclic sediments derived from the Beacon type rocks of East Antarctica and the sedimentary rocks of the Northern Antarctic Peninsula.

The Fourier grain shape signatures do not differ significantly between Site 693 and Sites 695, 696, and 697. Sphericity cannot be used to differentiate grain shape groups between these sites. Roundness can be used to differentiate three end members between all samples and all sites. The areal distribution of these three end members shows only small differences in areal distribution between Sites 693 and Sites 695, 696, and 697. The ternary mapping of proportional variations of the three end members shows no distinct shape groupings between Sites 693 and Sites 695, 696, and 697, and thus with this data base it is not possible to distinguish significant differences in grain shape between sites. Therefore the objective of evaluating the temporal changes in the sources of sediment to the central basin (Site 694) cannot be achieved.

Rather, the changes in the proportion of end members can be evaluated as an indication of changes in sedimentation patterns. For example, at Sites 693, 695, and 697, there is an increase in the proportion of end member 1 (crystalline, glacial) at the upper/ lower Pliocene boundary. Surface textures of these samples have larger amounts of fractured grains. This suggests that these samples are crystalline grains derived from crystalline rocks exposed to weathering or erosion by ice. At Site 696, the lower Oligocene sediments have very high proportions of angular grains. However, these samples do not have as high proportions of fractured grains or comminution debris indicative of weathering in a glacial environment. Thus these grains are angular crystalline grains that have fractured during formation or deformation, a distinction that can be made only through SEM analysis.

\section{CONCLUSIONS}

Analyses of the origin and distribution of very fine quartz sand grains in the Weddell Sea and their relationship to paleoceanography have provided a framework for the following conclusions:

1. On the basis of Fourier shape analysis, three major types of very fine quartz sand are present in the Weddell Sea in the Oligocene to Pleistocene sediments. The first sand type (angular, end member 1) is extremely angular and displays fractured textures. These sands are presumed to be derived from crystalline rocks that have fractured during formation or deformation and/or crystalline rocks exposed to weathering by ice. The second type of sand (intermediate, end member 2) is neither as angular as end member 1 nor as round as end member 3 and displays crystalline nodes and grain embayments. These grains are thought to have been derived from felsic intrusives and quartzites of East Antarctica, the basement metamorphics of South Orkney Microcontinent (SOM), and the Andean Intrusive series of West Antarctica. The third sand type (rounded end member 3 ) is rounded to subrounded and displays both chemically and mechanically produced surface textures, although the former predominates. These sands are presumed to be derived from the Beacon-type rocks in East Antarctica and from the sedimentary deposits of the Northern Antarctic Peninsula.

2. At the sampling interval used in this study, Fourier grain shape analyses do not show enough variation in grain shape to distinguish differences in provenance and transport history between Site 693 (East Antarctica) and Sites 695, 696, and 697 (West Antarctica). Therefore this method cannot be used to interpret the glacial history of sediments transported to the Weddell Sea basin (Site 694).

3. Fourier grain shape identification of angular grains is not directly correlative with glacial grains, but when combined with SEM identification of surface textures, can be used as an indication of a glacial environment.

4. Application of the Fourier method of describing surface shapes and textures is hampered by the necessity of studying material that is at least coarse silt or very fine sand size and commonly requires a relatively large sample size. The sampling requirement limited the sample density of this study and did not allow for the identification of high-resolution changes at or between sites.

\section{ACKNOWLEDGMENTS}

This paper was excerpted from a thesis (Smith, 1988) submitted in partial fulfillment of the Master of Science degree at Texas A\&M University. We thank Jim Mazzullo for the use of his equipment and helpful discussions about the application of Fourier grain shape analysis to the glacial history of Antarctica. Two other committee members, Audrey Meyer and Wilf Gardner, also provided many helpful comments. This chapter was substantially improved by reviews from Laura Stokking, Jim Kennett, and three anonymous reviewers. This study was supported by Leg 113 USSAC funds. 


\section{REFERENCES}

Adie, R. J., 1962. The geology of Antarctica. In Wexler, H., Rubin, M. H., and Caskey, J. E. (Eds.), Antarctic Research: Washington (American Geophysical Union), 26-39.

Anderson, J. B., Wright, R., and Andrews, B., 1986. Weddell Fan and associated abyssal plain, Antarctica: morphology, sediment processes and factors influencing sediment supply. Geo-Mar. Lett., 6:121-129.

Andrews, B. A., 1984. Petrology of Weddell Sea glacial sediments: implications for provenance and glacial history. Antarct. J. U.S., 18: 92-94.

Aucamp, A. P., Wolmarans, L. G., and Neethling, D. C., 1972. The Urfjell Group, a deformed Early Paleozoic sedimentary sequence, Kirwanveggen. In Adie, R. S. (Ed.), Antarctic Geology and Geophysics: Oslo (Scandinavian Univ. Press), 557-562.

Bauer, R. L., 1983. Low-grade metamorphism in the Heritage Range of the Ellsworth Mountains, West Antarctica. In Oliver, R. L., James, P. R., and Jago, J. B. (Eds.), Antarctic Earth Science: New York (Cambridge Univ. Press), 256-260.

Berggren, W. A., Kent, D. V., Flynn, J. J., and Van Couvering, J. A., 1985. Neogene geochronology and chronostratigraphy. In Snelling, N. J. (Ed.), Geochronology of the Geologic Record. Geol. Soc. London, Mem. 10:211-260.

Breddell, J. H., 1982. The Precambrian sedimentary-volcanic sequence and associated intrusive rocks of the Ahlmannryggen, Western Dronning Maud Land: a new interpretation. In Craddock, C. (Ed.), Antarctic Geoscience: Madison (Univ. Wisconsin Press), 591-598.

Clarkson, P. D., 1982. Tectonic significance of the Shackleton Range. In Craddock, C. (Ed.), Antarctic Geoscience: Madison (Univ. Wisconsin Press), 835-840.

Craddock, C., 1982. Antarctica and Gondwanaland. In Craddock, C. (Ed.), Antarctic Geoscience: Madison (Univ. Wisconsin Press), 314.

Dowdeswell, J. A., 1982. Scanning electron micrographs of quartz sand grains from cold environments examined using Fourier shape analysis. J. Sediment. Petrol., 52:1315-1323.

Dowdeswell, J. A., Osterman, L. E., and Andrews, J. T., 1985. Quartz sand grain shape and other criteria used to distinguish glacial and non-glacial events in a marine core from Frobisher Bay, Baffin Island, NWT, Canada. Sedimentology, 32:119-132.

Edwards, D. S., and Goodell, H. G., 1969. The detrital mineralogy of ocean floor surface sediments adjacent to the Antarctic Peninsula. Antarct. Mar. Geol., 7:207-234.

Eggers, M. R., and Ehrlich, R., 1987. Provenance changes of fine quartz sands in glacial and interglacial intervals of the Feni and Gardar drifts, North Atlantic: Fourier shape analysis. In Ruddiman, W. F., Kidd, R. B., Thomas, E., et al., Init. Repts. DSDP, 94: Washington (U.S. Govt. Printing Office), 1103-1107.

Ehrlich, R., Brown, J. P., Yarus, J. M., and Przygocki, R. S., 1980. The origin of shape frequency distributions and the relationship between size and shape. J. Sediment. Petrol., 50:475-484.

Ehrlich, R., and Weinberg, G., 1970. An exact method for the characterization of grain shape. J. Sediment. Petrol., 40:205-212.

Ehrlich, R., Kennedy, S. K., and Brotherhood, C. D., 1987. Respective roles of Fourier and SEM techniques in analyzing sedimentary quartz. In Marshall, J. R. (Ed.), Clastic Particles: New York (Van Nostrand Reinhold), 292-301.

Elliott, D. H., and Trautman, T. A., 1982. Lower Tertiary strata on Seymour Island, Antarctic Peninsula. In Craddock, C. (Ed.), Antarctic Geoscience: Wisconsin (Univ. Wisconsin Press), 287-297.

Full, W. E., Ehrlich, R., and Kennedy, S., 1984. Optimal configuration and information content of sample data generally displayed as histograms or frequency distributions. J. Sediment. Petrol., 49:599-610.

Griffiths, J., 1967. Scientific Method in the Analysis of Sediments: New York (McGraw-Hill).

Haines, J., and Mazzullo, J., 1988. Sources and distribution of late Quaternary silt in the surficial sediment of the northeastern continental shelf of the United States. Mar. Geol., 78:227-240.

Hamilton, N., 1965. Description of a bottom-sediment sample dredged from Halley Bay. Brit. Antarct. Surv. Bull., 7:47-52.

Hjelle, A., and Winsnes, T., 1972. The sedimentary and volcanic sequence of Vestfjella, Dronning Maud Land. In Adie, R. S. (Ed.), Antarctic Geology and Geophysics: Oslo (Scandinavian Univ. Press), 539-546.
Hudson, C. B., and Ehrlich, R., 1980. Determination of relative provenance contributions in samples of quartz using Q-mode factor analysis of Fourier grain shape data. J. Sediment. Petrol., 50:1101-1110.

Hughes, T. J., 1977. West Antarctic ice streams. Rev. Geophys. Space Phys., 15:1-46.

Klovan, J. E., and Miesch, A. T., 1976. Extended CABFAC and QMODEL computer programs for Q-mode factor analysis of compositional data. Comput. Geosci., 1:161-178.

Krinsley, D. H., and Donahue, J., 1968. Environmental interpretation of sand grain surface texture by electron microscopy. Geol. Soc. Am. Bull., 79:743-748.

Krinsley, D. H., and Doornkamp, J.C., 1973. Atlas of Quartz Sand Surface Features. Cambridge (Cambridge Univ. Press).

Krinsley, D. H., and Funnell, B. M., 1965. Environmental history of sand grains from the lower and middle Pleistocene of Norfolk, England. J. Geol. Soc. Lond., 121:435-461.

Krinsley, D. H., and Margolis, S. B., 1969. A study of quartz grain surface textures with scanning electron microscope. Trans. N.Y. Acad. Sci., 31:457-477.

Krinsley, D. H., and Marshall, J. R., 1987. Sand grain textural analysis: an assessment. In Marshall, J. R. (Ed.), Clastic Particles: New York (Van Nostrand Reinhold), 2-15.

Krinsley, D. H., and Takahashi, T., 1962. Applications of electron microscopy to geology. Trans. N.Y. Acad. Sci., 25:3-22.

Krinsley, D. H., Takahashi, T., Silberman, M. L., and Newman, W. S., 1964. Transportation of sand grains along the Atlantic shore of Long Island, New York-an application of electron microscopy. Mar. Geol, 2:100-120.

Krumbein, W. C., 1941. Measurement and geologic significance of shape and roundness of sedimentary particles. J. Sediment. Petrol., 11:64-72.

Laudon, T. S., Thomson, M. R., Williams, P. L., Milliken, K. L., Rowley, P. D., and Boyles, J. M., 1983. The Jurassic Latady Formation, Southern Antarctic Peninsula. In Oliver, R. L., James, P. R., and Jago, J. B. (Eds.), Antarctic Geoscience. New York (Cambridge University Press), 308-314.

Margolis, S. V., and Kennett, J. P., 1970. Antarctic glaciation during the Tertiary recorded in sub-Antarctic deep sea cores. Science, 170: 1085-1087.

1971. Cenozoic glacial history of Antarctica recorded in subAntarctic deep-sea cores. Am. Jour. Sci., 271:1-36.

Mazzullo, J., 1986. Sources and provinces of late Quaternary sand on the East Texas-Louisiana continental shelf. Geol. Soc. Am. Bull., 97:638-647.

Mazzullo, J., and Anderson, J. B., 1987. Grain shape and surface texture analysis of till and glacial-marine sand grains from the Weddell and Ross Seas, Antarctica. In Marshall, J. R. (Ed.), Clastic Particles: New York (Van Nostrand Reinhold), 314-327.

Mazullo, J., and Ehrlich, R., 1980. A vertical pattern of variation in the St. Peter sandstone-Fourier grain analysis. J. Sediment. Petrol., $50: 63-70$.

Mazzullo, J., and Kennedy, S., 1985. Automated measurement of the nominal section diameter of individual sedimentary particles. J. Sediment. Petrol., 55:593-595.

Mazzullo, J., and Magenheimer, S., 1987. The original shapes of quartz sand grains. J. Sediment. Petrol., 57:479-487.

Mazzullo, J., Ehrlich, R., and Pilkey, O. H., 1982. Local and distal sources of sand in the Hatteras Abyssal Plain: Fourier grain shape analysis. Mar. Geol., 48:75-88.

Miesch, A. T., 1976. Q-mode factor analysis of geochemical and petrologic data matrices with constant row sums. Geol. Surv. Prof. Pap. 574-G: Washington (U.S. Govt. Printing Office), 1-48.

Moss, A. J., 1966. Origin, shaping, and significance of quartz sand grains. J. Geol. Soc. Aust., 13:97-136.

Moss, A. J., and Green, P., 1975. Sand and silt grains: predetermination of their formation and properties by microfractures in quartz. $J$. Geol. Soc. Aust., 22:485-495.

Neethling, D. C., 1972. Age and correlation of the Ritscher Supergroup and other Precambrian rock units, Dronning Maud Land. In Adie, R. S. (Ed.), Antarctic Geology and Geophysics: Oslo (Scandinavian Univ. Press), 547-556.

Parkhurst, R. J., Marsh, P. D., and Clarkson, P. D., 1983. A geochronological investigation of the Shackleton Range. In Oliver, R. L., 
James, P. R., and Jago, J. B. (Eds.), Antarctic Earth Science. New York (Cambridge Univ. Press), 176-182.

Ritter, C., 1987. Shapes and surface textures of quartz sand grains from glacial deposits: effects of source and transport [M.S. thesis]. Texas A\&M Univ., College Station.

Rowley, P. D., Vennum, W. R., Kellogg, K. S., Laudon, T. S., Carrara, P. E., Boyles, J. M., and Thomson, M. R., 1983. Geology and plate tectonic setting of the Orville coast on eastern Ellsworth Land, Antarctica. In Oliver, R. L., James, P. R., and Jago, J. B. (Eds.), Antarctic Earth Science. New York (Cambridge Univ. Press), 245-250.

Schultz, D. J., 1980. The effect of hydrofluoric acid on quartz-shape: Fourier grain shape analysis. J. Sediment. Petrol., 50:644-645.

Shipboard Scientific Party, 1988. Sites 693-697. In Barker, P. F., Kennett, J. P., et al., Proc. ODP, Init. Repts., 113: College Station, TX (Ocean Drilling Program).

Smith, C. H., 1988. Provenance and glacial history of very fine quartz sand from the Weddell Sea, Antarctica [M.S. thesis]. Texas A\&M Univ., College Station.

Thomson, J. W., 1974. The geology of the South Orkney Islands: III. Coronation Island. Br. Antarct. Surv. Sci. Rept., 86:1-39.

Thomson, M.R.A., Parkhurst, R. J., and Clarkson, P. D., 1983. The Antarctic Peninsula-a Late Mesozoic-Cenozoic Arc (Review). In Oliver, R. L., James, P. R., and Jago, J. B. (Eds.), Antarctic Earth Science. New York (Cambridge Univ. Press), 289-294.

Date of initial receipt: 28 February 1989

Date of acceptance: 15 November 1989

Ms 113B-149

APPENDIX - TABLE 1

\begin{tabular}{|c|c|c|c|c|c|}
\hline \multirow[b]{2}{*}{ Hole } & \multirow{2}{*}{$\begin{array}{l}\text { Core, section, } \\
\text { interval }(\mathrm{cm})\end{array}$} & \multirow{2}{*}{$\begin{array}{l}\text { Depth } \\
\text { (mbsf) }\end{array}$} & \multicolumn{3}{|c|}{ Percentage of each member } \\
\hline & & & Angular & Intermediate & Rounded \\
\hline $693 \mathrm{~A}^{*}$ & $4 \mathrm{R} 027782$ & 24.21 & 0.31335 & 0.33580 & 0.33058 \\
\hline $693 A^{*}$ & $7 \mathrm{R} 027782$ & 53.07 & 0.25807 & 0.39163 & 0.35015 \\
\hline $693 A^{*}$ & $8 \mathrm{R} 027983$ & 62.69 & 0.60595 & 0.28003 & 0.11383 \\
\hline $693 A^{*}$ & 9R02 8084 & 72.40 & 0.31093 & 0.17963 & 0.50938 \\
\hline $693 \mathrm{~A}$ & $11 R 048084$ & 94.60 & 0.13855 & 0.37108 & 0.49035 \\
\hline $693 \mathrm{~A}$ & $12 \mathrm{R} 028084$ & 101.20 & 0.17180 & 0.26185 & 0.56753 \\
\hline $693 A^{*}$ & $13 \mathrm{R} 028084$ & 110.90 & 0.07125 & 0.31620 & 0.61238 \\
\hline $693 A^{*}$ & $15 \mathrm{R} 028084$ & 130.10 & 0.21750 & 0.40003 & 0.38238 \\
\hline $693 A^{*}$ & $16 \mathrm{R} 018183$ & 138.31 & 0.01853 & 0.31315 & 0.66830 \\
\hline $693 \mathrm{~A}$ & $18 \mathrm{R} 028183$ & 159.21 & 0.14177 & 0.40178 & 0.45625 \\
\hline $693 A^{*}$ & 19R02 8084 & 168.90 & 0.06505 & 0.30540 & 0.62950 \\
\hline $693 \mathrm{~A}$ & $21 R 027983$ & 187.94 & 0.23848 & 0.30643 & 0.45500 \\
\hline $693 A^{*}$ & $25 R 028183$ & 226.91 & 0.06005 & 0.37953 & 0.50630 \\
\hline $693 A^{*}$ & 26R02 7983 & 236.59 & 0.23985 & 0.20095 & 0.55918 \\
\hline $693 \mathrm{~A}$ & $27 R 02 \quad 38 \quad 42$ & 245.78 & 0.31945 & 0.43292 & 0.24745 \\
\hline $693 A^{*}$ & 28R02 8185 & 255.91 & 0.18225 & 0.26730 & 0.55077 \\
\hline $693 \mathrm{~A}$ & $31 \mathrm{R} 017984$ & 282.99 & 0.15238 & 0.34085 & 0.50670 \\
\hline $693 A^{*}$ & 33R01 9095 & 302.40 & 0.25020 & 0.31595 & 0.43390 \\
\hline $693 \mathrm{~A}$ & 38R01 8286 & 350.72 & 0.34903 & 0.29037 & 0.36065 \\
\hline $693 A^{*}$ & $39 R 02 \quad 7983$ & 361.89 & 0.42175 & 0.31105 & 0.26720 \\
\hline $693 \mathrm{~A}$ & 40R02 7983 & 371.19 & 0.26088 & 0.35545 & 0.38370 \\
\hline $693 A^{*}$ & 43R01 $18 \quad 20$ & 397.28 & 0.37365 & 0.23893 & 0.36240 \\
\hline $693 \mathrm{~A}$ & 43R01 $28 \quad 30$ & 397.38 & 0.33672 & 0.12935 & 0.53392 \\
\hline $693 \mathrm{~B}$ & $2 \times 03 \quad 38 \quad 42$ & 237.18 & 0.31940 & 0.33858 & 0.34200 \\
\hline 693B & $6 \mathrm{H} 03 \quad 3840$ & 271.18 & 0.22233 & 0.29130 & 0.48635 \\
\hline $693 \mathrm{~B}^{*}$ & $7 \mathrm{H} 033742$ & 280.87 & 0.30878 & 0.27823 & 0.41298 \\
\hline 693B & $8 \times 03 \quad 4145$ & 290.51 & 0.48375 & 0.26857 & 0.24765 \\
\hline 693B & $10 \times 03 \quad 3741$ & 309.87 & 0.23773 & 0.27898 & 0.48330 \\
\hline 693B & $11 \times 018387$ & 316.93 & 0.26645 & 0.38870 & 0.34488 \\
\hline 693B & $12 \times 03 \quad 3742$ & 329.17 & 0.11395 & 0.34020 & 0.54540 \\
\hline 693B & $14 \times 03 \quad 3742$ & 348.47 & 0.26520 & 0.28105 & 0.45378 \\
\hline 693B & $15 \times 03 \quad 3539$ & 358.05 & 0.22950 & 0.34003 & 0.43045 \\
\hline $693 \mathrm{~B}^{*}$ & $16 \times 03 \quad 37 \quad 42$ & 367.77 & 0.29022 & 0.38705 & 0.32295 \\
\hline 693B & $17 \times 013741$ & 374.37 & 0.31518 & 0.32375 & 0.36108 \\
\hline $693 \mathrm{~B}$ & $18 \times 056063$ & 390.30 & 0.43317 & 0.36390 & 0.20292 \\
\hline
\end{tabular}

* Indicates samples that were selected for SEM analysis and point counting.
APPENDIX - TABLE 2

\begin{tabular}{|c|c|c|c|c|c|}
\hline \multirow[b]{2}{*}{ Hole } & \multirow{2}{*}{$\begin{array}{l}\text { Core, section, } \\
\text { interval }(\mathrm{cm})\end{array}$} & \multirow{2}{*}{$\begin{array}{l}\text { Depth } \\
\text { (mbsf) }\end{array}$} & \multicolumn{3}{|c|}{ Percentage of each member } \\
\hline & & & Angular & Intermediate & Rounded \\
\hline 694B & $1 \mathrm{H} 023335$ & 1.83 & 0.30001 & 0.31047 & 0.38950 \\
\hline 694B & $1 \mathrm{H} 04 \quad 12 \quad 14$ & 4.62 & 0.28420 & 0.29278 & 0.42305 \\
\hline 694B & $2 \mathrm{H} 027173$ & 7.71 & 0.42308 & 0.27445 & 0.30225 \\
\hline $694 \mathrm{~B}$ & $2 \mathrm{H} 03 \quad 111 \quad 113$ & 9.61 & 0.56965 & 0.05295 & 0.37743 \\
\hline $694 \mathrm{~B}$ & $2 \mathrm{H} 057274$ & 12.22 & 0.23850 & 0.37953 & 0.38200 \\
\hline $694 \mathrm{~B}$ & $3 \mathrm{H} 02 \quad 38 \quad 40$ & 16.98 & 0.32092 & 0.27845 & 0.40067 \\
\hline 694B & $3 \mathrm{H} 038789$ & 18.97 & 0.28610 & 0.38715 & 0.32675 \\
\hline $694 \mathrm{~B}^{*}$ & $3 \mathrm{H} 07911$ & 24.19 & 0.17877 & 0.28565 & 0.43563 \\
\hline 694B & $3 \mathrm{HCC} 2225$ & 24.55 & 0.31168 & 0.28978 & 0.39858 \\
\hline $694 \mathrm{~B}$ & $4 \times 01 \quad 6872$ & 25.38 & 0.24297 & 0.35753 & 0.39948 \\
\hline $694 \mathrm{~B}^{*}$ & $5 \times 013034$ & 34.6 & 0.31712 & 0.23303 & 0.44990 \\
\hline $694 \mathrm{~B}^{*}$ & $6 \mathrm{H} 01 \quad 20 \quad 22$ & 44.20 & 0.17607 & 0.31260 & 0.51133 \\
\hline $694 \mathrm{~B}$ & $\begin{array}{lll}6 \mathrm{H} 02 & 17 \quad 19\end{array}$ & 45.67 & 0.24585 & 0.45165 & 0.30253 \\
\hline $694 \mathrm{~B}^{*}$ & $9 \mathrm{HOI} 2022$ & 73.00 & 0.41815 & 0.33635 & 0.24550 \\
\hline $694 \mathrm{~B}$ & $9 \mathrm{H} 015961$ & 73.39 & 0.24645 & 0.36538 & 0.38818 \\
\hline $694 \mathrm{~B}^{*}$ & $10 \mathrm{H} 01 \quad 105 \quad 109$ & 83.55 & 0.18295 & 0.27363 & 0.54350 \\
\hline $694 \mathrm{~B}$ & $10 \mathrm{H} 023134$ & 84.31 & 0.23417 & 0.37550 & 0.39033 \\
\hline 694B & $10 \mathrm{H} 028084$ & 84.80 & 0.28370 & 0.27563 & 0.44063 \\
\hline $694 \mathrm{~B}^{*}$ & $14 \mathrm{H} 01 \quad 122 \quad 126$ & 112.72 & 0.24107 & 0.33015 & 0.42878 \\
\hline 694B* & $22 \mathrm{XCC} 911$ & 153.65 & 0.33400 & 0.23562 & 0.37578 \\
\hline 694B & $23 \times 058892$ & 166.88 & 0.32722 & 0.31468 & 0.35690 \\
\hline $694 B^{*}$ & $24 \times 02 \quad 108 \quad 112$ & 172.18 & 0.78113 & 0.11748 & 0.10140 \\
\hline $694 \mathrm{~B}^{*}$ & $24 \times 04 \quad 105 \quad 109$ & 175.15 & 0.15953 & 0.28142 & 0.55905 \\
\hline $694 C^{*}$ & $5 \times 0213$ & 210.41 & 0.21753 & 0.35573 & 0.42675 \\
\hline $694 \mathrm{C}$ & $5 \times 027074$ & 211.10 & 0.18653 & 0.38888 & 0.42455 \\
\hline $694 \mathrm{C}$ & $6 \times 0459$ & 222.45 & 0.29882 & 0.45413 & 0.24708 \\
\hline $694 C^{*}$ & $\begin{array}{llll}6 \times 04 & 100 & 104\end{array}$ & 223.40 & 0.34802 & 0.27920 & 0.37278 \\
\hline $694 \mathrm{C}$ & $8 \times C C 36$ & 238.63 & 0.16818 & 0.27895 & 0.55285 \\
\hline $694 \mathrm{C}$ & $\begin{array}{lll}10 \times 01 \quad 121 \quad 123\end{array}$ & 257.31 & 0.17230 & 0.36948 & 0.45 \\
\hline $694 C^{*}$ & $10 \times C C 3436$ & 258.77 & 0.24520 & 0.35792 & 0.39687 \\
\hline $694 \mathrm{C}$ & $11 \times 02111 \quad 113$ & 268.11 & 0.23590 & 0.33618 & 0.42793 \\
\hline $694 \mathrm{C}$ & $11 \times C C 2022$ & 268.44 & 0.15468 & 0.30225 & 0.54305 \\
\hline $694 C$ & $\begin{array}{lll}12 \times 01 & 130 & 132\end{array}$ & 276.80 & 0.23945 & 0.36652 & 0.39405 \\
\hline $694 \mathrm{C}$ & $12 \times C C 610$ & 277.55 & 0.10395 & 0.37405 & 0.52200 \\
\hline $694 C^{*}$ & $\begin{array}{lll}13 \times 01 & 130 & 132\end{array}$ & 286.40 & 0.06045 & 0.38250 & 0.54708 \\
\hline $694 \mathrm{C}$ & $13 \times C C 910$ & 286.98 & 0.22963 & 0.32130 & 0.44908 \\
\hline $694 \mathrm{C}$ & $14 \times 03 \quad 140 \quad 145$ & 299.10 & 0.15223 & 0.37560 & 0.47223 \\
\hline $694 \mathrm{C}$ & $14 \times 06 \quad 140 \quad 145$ & 303.60 & 0.15278 & 0.28190 & 0.56530 \\
\hline $694 C^{*}$ & $15 \times 018082$ & 305.10 & 0.29772 & 0.32515 & 0.37710 \\
\hline $694 \mathrm{C}$ & $18 \times 015255$ & 333.82 & 0.29880 & 0.29718 & 0.40407 \\
\hline $694 \mathrm{C}$ & $\begin{array}{lll}19 \times 01 & 145 & 149\end{array}$ & 344.45 & 0.45330 & 0.24860 & 0.29812 \\
\hline $694 C$ & $22 \times 015456$ & 372.54 & 0.19978 & 0.33770 & 0.46250 \\
\hline $694 C^{*}$ & $22 \times 016163$ & 372.61 & 0.15080 & 0.43323 & 0.41595 \\
\hline
\end{tabular}

* Indicates samples that were selected for SEM analysis and point counting. 
APPENDIX - TABLE 4

APPENDIX - TABLE 3

\begin{tabular}{|c|c|c|c|c|c|}
\hline \multirow[b]{2}{*}{ Hole } & \multirow{2}{*}{$\begin{array}{l}\text { Core, section, } \\
\text { interval }(\mathrm{cm})\end{array}$} & \multirow{2}{*}{$\begin{array}{l}\text { Depth } \\
\text { (mbsf) }\end{array}$} & \multicolumn{3}{|c|}{ Percentage of each member } \\
\hline & & & Angular & Intermediate & Rounded \\
\hline $695 \mathrm{~A}$ & $1 \mathrm{H} 02 \quad 146 \quad 148$ & 2.96 & 0.24168 & 0.33692 & 0.42140 \\
\hline $695 \mathrm{~A}$ & $1 \mathrm{H} 047678$ & 5.26 & 0.23953 & 0.38685 & 0.37360 \\
\hline $695 \mathrm{~A}$ & $2 \mathrm{H01} \quad 68 \quad 70$ & 3.58 & 0.32895 & 0.24388 & 0.42720 \\
\hline 695A & $2 \mathrm{H} 02 \quad 112 \quad 114$ & 5.52 & 0.24080 & 0.39730 & 0.36178 \\
\hline $695 A^{*}$ & $4 \mathrm{H} 02 \quad 108 \quad 110$ & 24.58 & 0.39635 & 0.40920 & 0.19445 \\
\hline $695 \mathrm{~A}$ & $4 \mathrm{H} 03 \quad 3941$ & 25.39 & 0.13098 & 0.36863 & 0.50168 \\
\hline $695 \mathrm{~A}$ & $4 \mathrm{H} 05 \quad 108 \quad 110$ & 29.00 & 0.12900 & 0.42085 & 0.45015 \\
\hline $695 \mathrm{~A}$ & $4 \mathrm{H} 0679$ & 29.49 & 0.22870 & 0.31763 & 0.45365 \\
\hline $695 A^{*}$ & $\begin{array}{lll}5 \mathrm{H} 02 & 108 \quad 112\end{array}$ & 34.18 & 0.12963 & 0.56900 & 0.30138 \\
\hline $695 A^{*}$ & $7 \mathrm{H} 0348$ & 53.84 & 0.62682 & 0.25350 & 0.11968 \\
\hline $695 \mathrm{~A}^{*}$ & $8 \mathrm{H} 018486$ & 61.24 & 0.55665 & 0.19020 & 0.25315 \\
\hline 695A & $8 \mathrm{H} 046163$ & 65. & 0.18 & 88 & 0.44905 \\
\hline 695A & $9 \mathrm{H} 01 \quad 113115$ & 71.13 & 0.297 & 0.327 & 0.37490 \\
\hline $695 \mathrm{~A}^{*}$ & $9 \mathrm{H} 03 \quad 8589$ & 73.85 & 0.20055 & 0.33268 & 0.46678 \\
\hline 695A & $12 \mathrm{H} 05 \quad 134138$ & 96.54 & 0.21862 & 0.27710 & 0.50425 \\
\hline 695A & $13 \mathrm{H} 028084$ & 101.10 & 0.12855 & 0.40933 & 0.46215 \\
\hline $695 \mathrm{~A}$ & $20 \times 02113116$ & 159.63 & 0.26265 & 0.40045 & 0.33690 \\
\hline $695 \mathrm{~A}$ & $20 \times 0599103$ & 163.99 & 0.25 & 0.29 & 0.45425 \\
\hline $695 \mathrm{~A}^{*}$ & $21 \times 02 \quad 107109$ & 169.37 & 0.17447 & 0.25958 & 0.56593 \\
\hline $695 \mathrm{~A}$ & $21 \times 04 \quad 107 \quad 109$ & 172.37 & 0.25082 & 0.24810 & 0.50108 \\
\hline $695 \mathrm{~A}^{*}$ & $\begin{array}{lll}22 \times 02 & 108 & 110\end{array}$ & 179.08 & 0.40600 & 0.22110 & 0.37365 \\
\hline 695A & $22 \times 0597 \quad 101$ & 183.47 & 0.22643 & 0.20050 & 0.43008 \\
\hline $695 A^{*}$ & $23 \mathrm{X} 026266$ & 188.32 & 0.18028 & 0.35383 & 0.46587 \\
\hline $695 \mathrm{~A}$ & $23 \times 046064$ & 191.30 & 0.22368 & 0.41645 & 0.35985 \\
\hline $695 A^{*}$ & $\begin{array}{llll}25 \times 05 & 140 & 144\end{array}$ & 203.30 & 0.29965 & 0.29078 & 0.40955 \\
\hline $695 \mathrm{~A}$ & $26 \times 02 \quad 16 \quad 18$ & 207.26 & 0.32237 & 0.38210 & 0.39553 \\
\hline $695 \mathrm{~A}^{*}$ & $27 \times 01 \quad 107 \quad 111$ & 216.37 & 0.21085 & 0.32883 & 0.46033 \\
\hline $695 \mathrm{~A}$ & $27 X 06 \quad 6872$ & 223.48 & 0.23240 & 0.27933 & 0.48075 \\
\hline $695 \mathrm{~A}$ & $28 \times 018791$ & 225.87 & 0.33895 & 0.22288 & 0.43805 \\
\hline $695 \mathrm{~A}^{*}$ & $28 \times 02 \quad 2933$ & 226.79 & 0.38433 & 0.28070 & 0.33498 \\
\hline $695 \mathrm{~A}^{*}$ & $\begin{array}{lll}30 \times 03 & 110 & 114\end{array}$ & 248.50 & 0.25180 & 0.48760 & 0.26057 \\
\hline $695 \mathrm{~A}^{*}$ & $32 \times 05 \quad 108 \quad 110$ & 261.18 & 0.54013 & 0.22895 & 0.23133 \\
\hline $695 \mathrm{~A}^{*}$ & $\begin{array}{lll}33 \times 02 & 100 & 104\end{array}$ & 266.30 & 0.30865 & 0.33543 & 0.35592 \\
\hline $695 \mathrm{~A}$ & $\begin{array}{llll}34 \times 03 & 140 & 143\end{array}$ & 277.90 & 0.35368 & 0.36658 & 0.28977 \\
\hline $695 \mathrm{~A}^{*}$ & $35 \times 029597$ & 285.55 & 0.37453 & 0.31805 & 0.30742 \\
\hline $695 \mathrm{~A}$ & $\begin{array}{lll}37 \times 02 & 100 & 102\end{array}$ & 304.90 & 0.42370 & 0.37775 & 0.19820 \\
\hline $695 \mathrm{~A}$ & $\begin{array}{lll}37 \times 05 & 108 & 110\end{array}$ & 309.48 & 0.33830 & 0.36797 & 0.00000 \\
\hline $695 \mathrm{~A}^{*}$ & $39 \times 02 \quad 113 \quad 115$ & 314.63 & 0.49033 & 0.28622 & 0.22343 \\
\hline $695 \mathrm{~A}$ & $39 \times 05 \quad 4143$ & 318.41 & 0.16935 & 0.41633 & 0.41433 \\
\hline 695A & $40 \times 026163$ & 323.81 & 0.25415 & 0.34203 & 0.40380 \\
\hline $695 \mathrm{~A}$ & $41 \times 024145$ & 333.31 & 0.34593 & 0.29770 & 0.35635 \\
\hline $695 \mathrm{~A}$ & $41 \times 053943$ & 337.79 & 0.23423 & 0.37255 & 0.39320 \\
\hline
\end{tabular}

* Indicates samples that were selected for SEM analysis and point counting.

\begin{tabular}{|c|c|c|c|c|c|}
\hline \multirow[b]{2}{*}{ Hole } & \multirow{2}{*}{$\begin{array}{l}\text { Core, section, } \\
\text { interval }(\mathrm{cm})\end{array}$} & \multirow{2}{*}{$\begin{array}{l}\text { Depth } \\
\text { (mbsf) }\end{array}$} & \multicolumn{3}{|c|}{ Percentage of each member } \\
\hline & & & Angular & Intermediate & Rounded \\
\hline 696A & 2H01 109111 & 3.59 & 0.28503 & 0.38063 & 0.33345 \\
\hline $696 \mathrm{~A}$ & $2 \mathrm{H} 043841$ & 7.38 & 0.34295 & 0.31622 & 0.34080 \\
\hline 696A & $2 \mathrm{H} 065759$ & 10.57 & 0.24403 & 0.39568 & 0.36030 \\
\hline $696 \mathrm{~A}$ & $5 \mathrm{H} 01 \quad 110 \quad 112$ & 32.30 & 0.33740 & 0.23593 & 0.42670 \\
\hline $696 \mathrm{~A}$ & 5H03 6466 & 34.84 & 0.34125 & 0.30580 & 0.35183 \\
\hline 696A & $6 \mathrm{H} 03 \quad 104 \quad 106$ & 44.84 & 0.23555 & 0.31685 & 0.44755 \\
\hline $696 \mathrm{~A}$ & $6 \mathrm{H} 055153$ & 47.31 & 0.27040 & 0.32093 & 0.40865 \\
\hline $696 \mathrm{~A}$ & $7 \mathrm{H} 043436$ & 55.24 & 0.23380 & 0.36093 & 0.40523 \\
\hline $696 \mathrm{~A}$ & $\begin{array}{lll}7 \mathrm{H} 05 & 145 & 147\end{array}$ & 57.85 & 0.21400 & 0.48493 & 0.30110 \\
\hline $696 \mathrm{~A}^{*}$ & $8 \mathrm{H} 01 \quad 70 \quad 72$ & 60.70 & 0.47558 & 0.24140 & 0.28537 \\
\hline $696 \mathrm{~A}$ & $8 \mathrm{H} 03 \quad 110 \quad 112$ & 64.10 & 0.31083 & 0.29075 & 0.39840 \\
\hline $696 A^{*}$ & $9 \mathrm{H} 04 \quad 111 \quad 115$ & 75.21 & 0.16755 & 0.33995 & 0.49143 \\
\hline $696 \mathrm{~A}^{*}$ & $9 \mathrm{HO6} 4549$ & 77.55 & 0.32990 & 0.43775 & 0.23233 \\
\hline 696B & $3 R 027074$ & 88.40 & 0.27158 & 0.29680 & 0.43165 \\
\hline $696 \mathrm{~B}^{*}$ & $\begin{array}{lll}3 R 04 & 138 \quad 140\end{array}$ & 92.08 & 0.14450 & 0.41535 & 0.44015 \\
\hline 696B & 5R03 9092 & 109.40 & 0.16910 & 0.18780 & 0.57713 \\
\hline 696B & $\begin{array}{lll}6 R 01 & 140 & 144\end{array}$ & 116.60 & 0.29805 & 0.37178 & 0.33015 \\
\hline 696B & $6 R 03 \quad 101 \quad 103$ & 119.21 & 0.38363 & 0.19865 & 0.41772 \\
\hline 696B & $7 R 036266$ & 128.42 & 0.31852 & 0.35298 & 0.35350 \\
\hline 696B & $\begin{array}{lll}7 R 03 & 132 \quad 137\end{array}$ & 129.12 & 0.36628 & 0.38599 & 0.24773 \\
\hline 696B & 7R04 49 & 129.34 & 0.39185 & 0.17670 & 0.43148 \\
\hline 696B & $12 \mathrm{R} 016064$ & 164.10 & 0.28350 & 0.26175 & 0.45475 \\
\hline $696 \mathrm{~B}$ & $17 \mathrm{R} 017579$ & 212.55 & 0.26540 & 0.29540 & 0.43920 \\
\hline $696 B^{*}$ & 20R01 7577 & 231.85 & 0.18258 & 0.41535 & 0.40208 \\
\hline 696B & 20R02 7577 & 233.35 & 0.27338 & 0.40175 & 0.32490 \\
\hline 696B & 20R03 7577 & 234.85 & 0.33205 & 0.27768 & 0.39028 \\
\hline 696B* & $21 R 03711$ & 243.87 & 0.40472 & 0.43163 & 0.16365 \\
\hline 696B & 23R01 5052 & 260.60 & 0.55550 & 0.28803 & 0.15648 \\
\hline $696 \mathrm{~B}^{*}$ & $23 R 035052$ & 263.60 & 0.64595 & 0.29458 & 0.05948 \\
\hline 696B* & 24R01 9094 & 270.60 & 0.43220 & 0.23633 & 0.33150 \\
\hline 696B* & 25R01 107109 & 280.47 & 0.18263 & 0.46553 & 0.35185 \\
\hline 696B & 26R01 2732 & 289.27 & 0.34168 & 0.33973 & 0.31860 \\
\hline 696B & 26R02 $38 \quad 43$ & 290.88 & 0.33050 & 0.32985 & 0.33963 \\
\hline 696B & 26R03 $37 \quad 42$ & 292.37 & 0.29255 & 0.26298 & 0.44448 \\
\hline 696B & 28R01 $107 \quad 111$ & 309.37 & 0.35735 & 0.36513 & 0.27750 \\
\hline 696B & $28 \mathrm{R} 03 \quad 107 \quad 111$ & 312.37 & 0.33883 & 0.36285 & 0.29827 \\
\hline $696 \mathrm{~B}^{*}$ & $53 \mathrm{R} 028082$ & 551.20 & 0.37218 & 0.38800 & 0.23985 \\
\hline 696B & $\begin{array}{llll}54 \mathrm{R} 02 & 100 & 103\end{array}$ & 561.00 & 0.35113 & 0.24443 & 0.40448 \\
\hline 696B & $54 \mathrm{R} 0426$ & 563.02 & 0.53215 & 0.17965 & 0.28835 \\
\hline 696B & $\begin{array}{lll}59 R 02 & 107 & 111\end{array}$ & 609.47 & 0.60275 & 0.26098 & 0.13625 \\
\hline $696 \mathrm{~B}^{*}$ & $\begin{array}{lll}59 R 05 & 107 & 111\end{array}$ & 613.97 & 0.56833 & 0.35387 & 0.07783 \\
\hline 696B & $\begin{array}{lll}60 \mathrm{R} 02 & 102 \quad 104\end{array}$ & 619.12 & 0.54145 & 0.30913 & 0.14945 \\
\hline 696B & 60R05 $102 \quad 104$ & 623.62 & 0.47883 & 0.32535 & 0.19583 \\
\hline 696B & $61 R 01111115$ & 627.31 & 0.56360 & 0.23940 & 0.19700 \\
\hline $696 \mathrm{~B}^{*}$ & $61 R 03114118$ & 630.34 & 0.44745 & 0.32362 & 0.22893 \\
\hline 696B & 62R02 $78 \quad 81$ & 637.09 & 0.45888 & 0.37203 & 0.16908 \\
\hline 696B & $62 R 077477$ & 644.55 & 0.64852 & 0.19233 & 0.15915 \\
\hline
\end{tabular}

* Indicates samples that were selected for SEM analysis and point counting.

APPENDIX - TABLE 5

\begin{tabular}{|c|c|c|c|c|c|}
\hline \multirow[b]{2}{*}{ Hole } & \multirow{2}{*}{$\begin{array}{l}\text { Core, section, } \\
\text { interval }(\mathrm{cm})\end{array}$} & \multirow{2}{*}{$\begin{array}{l}\text { Depth } \\
\text { (mbsf) }\end{array}$} & \multicolumn{3}{|c|}{ Percentage of each member } \\
\hline & & & Angular & Intermediate & Rounded \\
\hline $697 \mathrm{~B}$ & $10 \mathrm{H} 02 \quad 2225$ & 106.42 & 0.21508 & 0.31033 & 0.47463 \\
\hline 697B* & $12 \times 015983$ & 120.39 & 0.14835 & 0.38903 & 0.46263 \\
\hline $697 \mathrm{~B}$ & $16 \times 02 \quad 10 \quad 12$ & 159.10 & 0.13375 & 0.34063 & 0.52562 \\
\hline $697 B^{*}$ & $16 \times 037577$ & 161.25 & 0.51585 & 0.31402 & 0.17015 \\
\hline $697 \mathrm{~B}$ & $29 \times 03 \quad 25 \quad 27$ & 286.55 & 0.31400 & 0.37170 & 0.31593 \\
\hline $697 \mathrm{~B}$ & $30 \times 013640$ & 293.36 & 0.23505 & 0.37475 & 0.39018 \\
\hline $697 \mathrm{~B}^{*}$ & $\begin{array}{lll}30 \times 03 & 123 \quad 127\end{array}$ & 297.23 & 0.16275 & 0.31660 & 0.52058 \\
\hline 697B & $31 \times 023741$ & 304.47 & 0.19763 & 0.39140 & 0.41098 \\
\hline 697B & $\begin{array}{lll}31 \times 03 & 83 & 87\end{array}$ & 306.43 & 0.32705 & 0.25848 & 0.41447 \\
\hline $697 \mathrm{~B}^{*}$ & $32 \times 0498 \quad 100$ & 317.68 & 0.54610 & 0.24560 & 0.20830 \\
\hline
\end{tabular}

* Indicates samples that were selected for SEM analysis and point counting. 

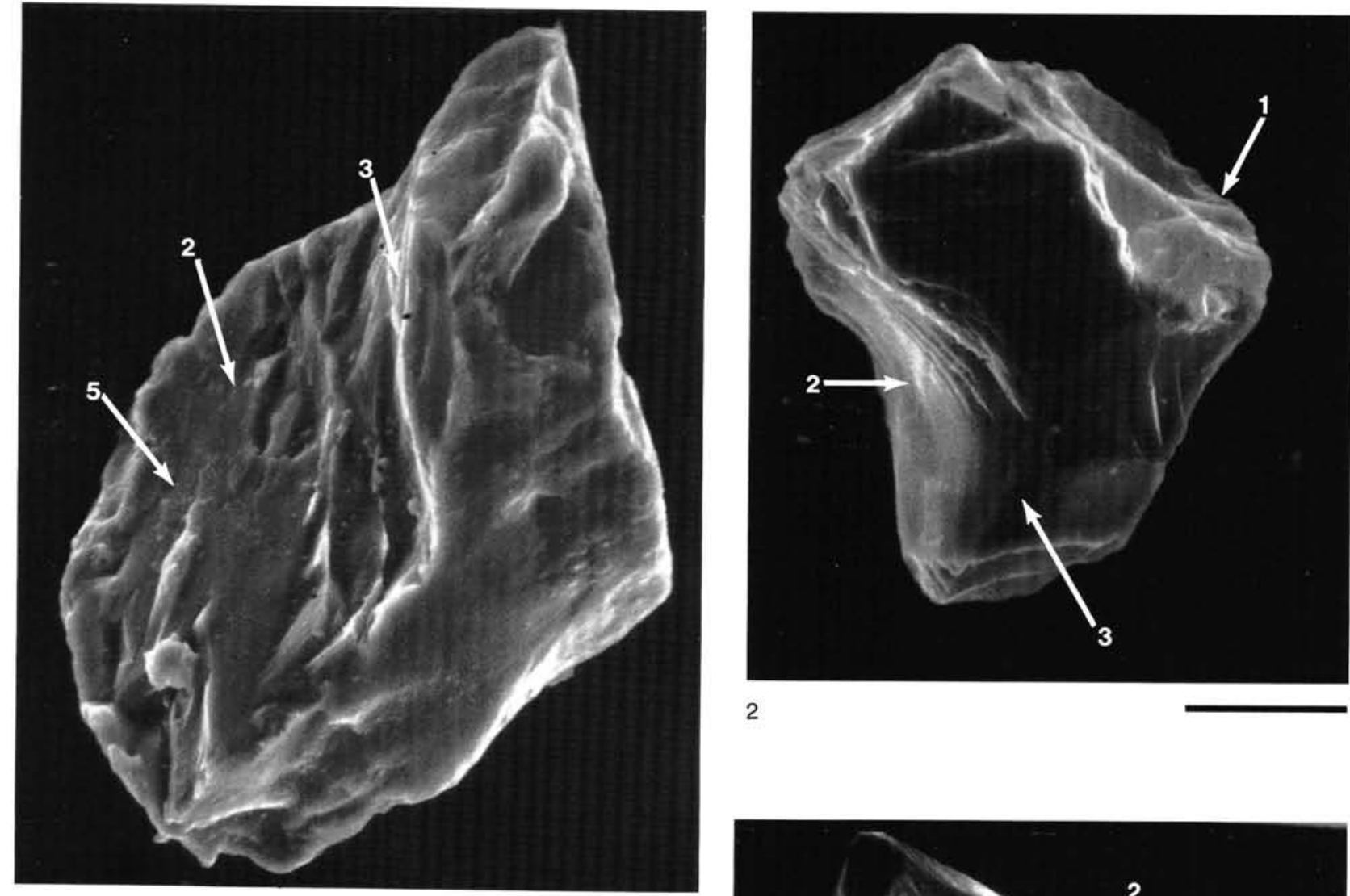

2

1

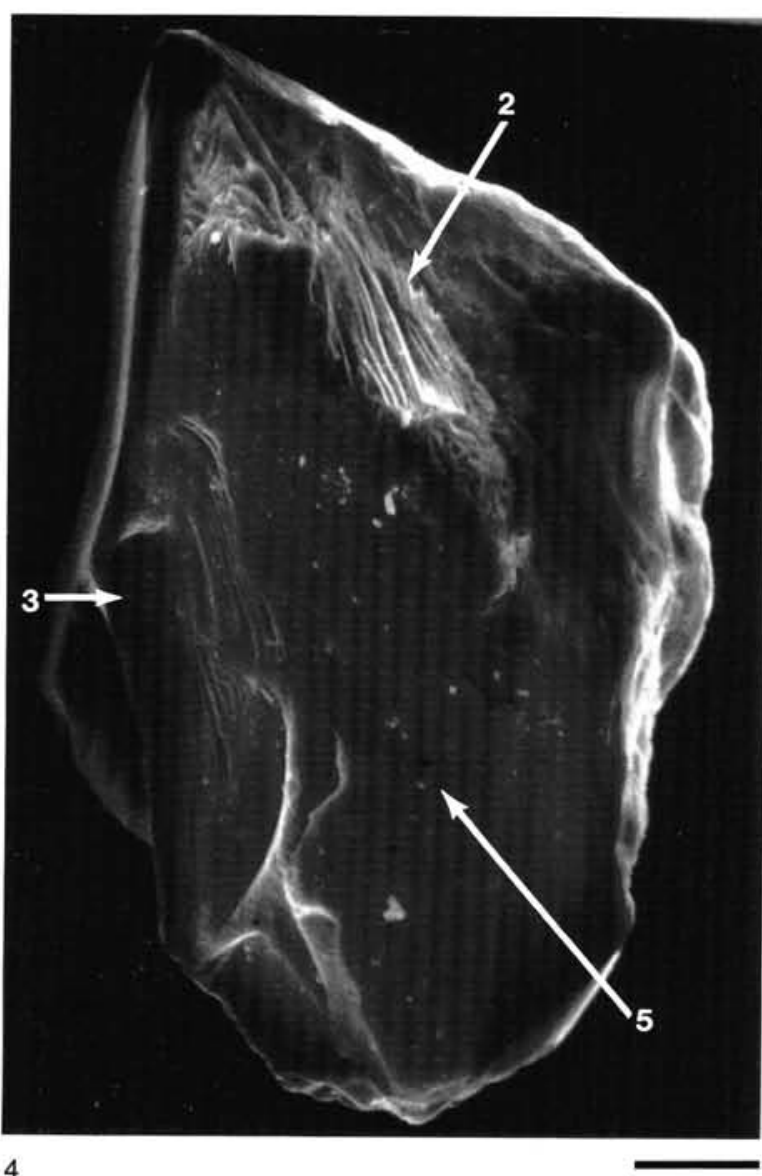

3
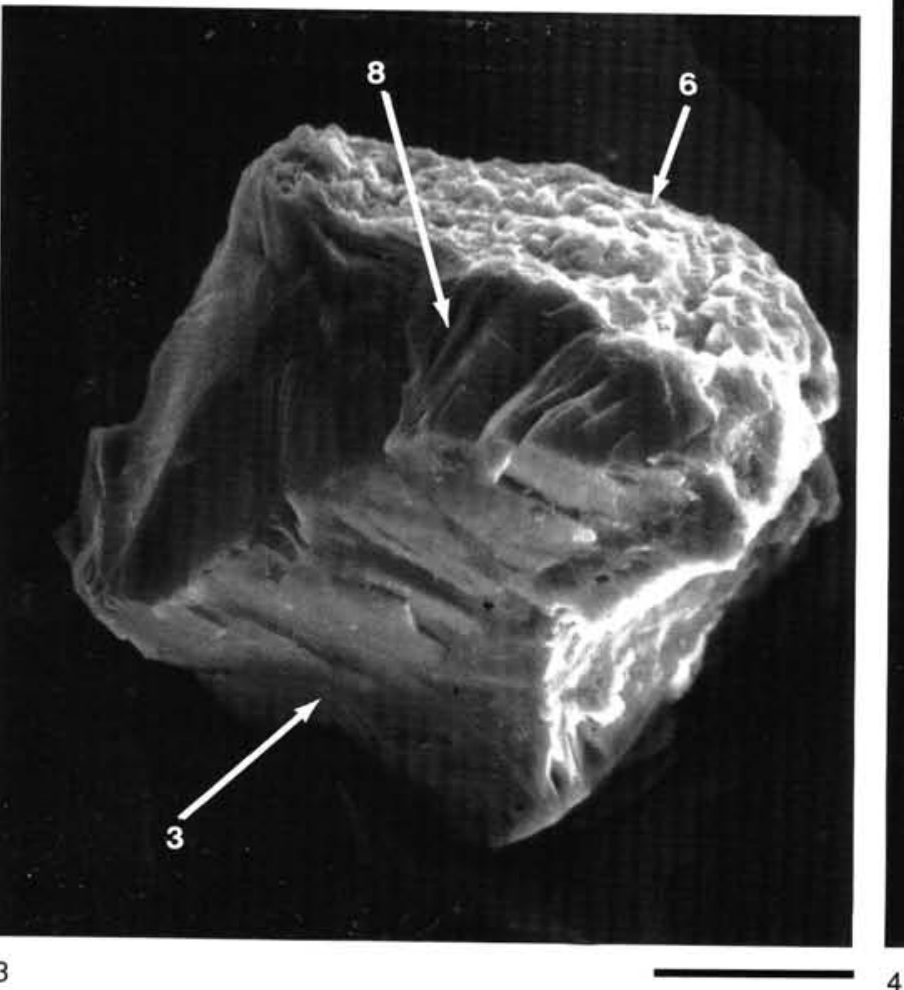

Plate 1. SEM photographs of angular end member very fine quartz sand. Bar scale on each photograph represents $20 \mu \mathrm{m}$. The numbers correspond to features identified in the caption. 1. Angular grain showing large-scale conchoidal fracturing (2), comminution debris (5), and microfractures (3). Sample 113-695A-25X-2, 140-144 cm. 2. Angular grain showing microfractures (2), microblocks (1), and large-scale conchoidal fractures (3). Sample 113-697B-32X-4, 98-100 cm. 3. Angular grain showing large-scale conchoidal fractures (3), parallel and arc-shaped steps (8), and upturned plates (6). Sample 113-695A-5H-2, $108 \mathrm{~cm}$. 4. Angular grain showing large-scale conchoidal fractures (3), microfractures (2), and comminution debris (5). Sample 113-693A-8R, 79-83 cm. 


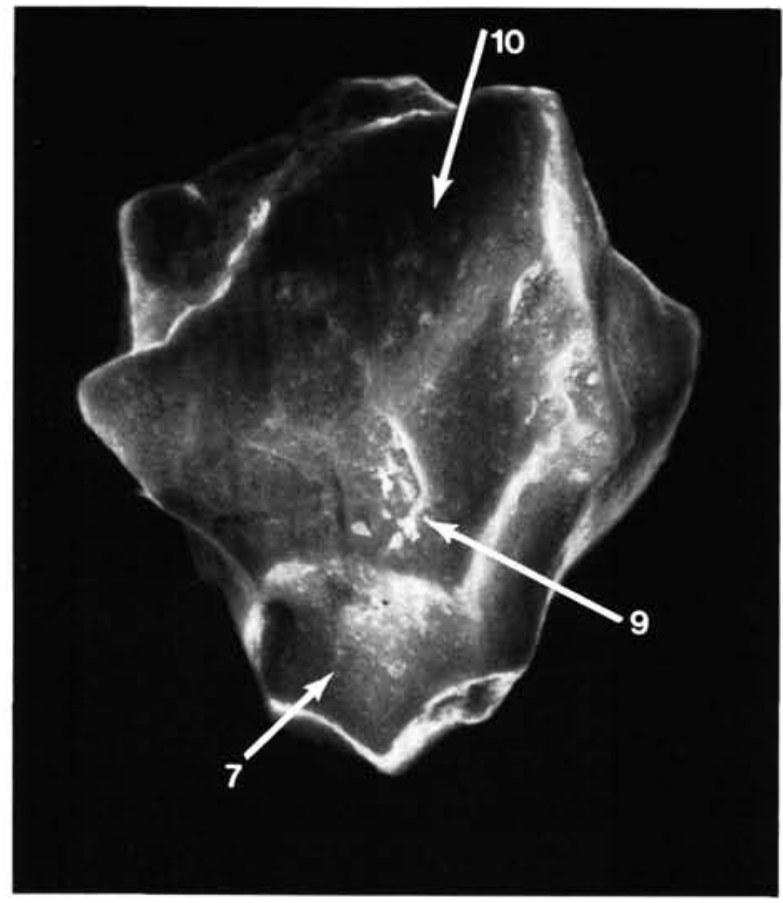

1

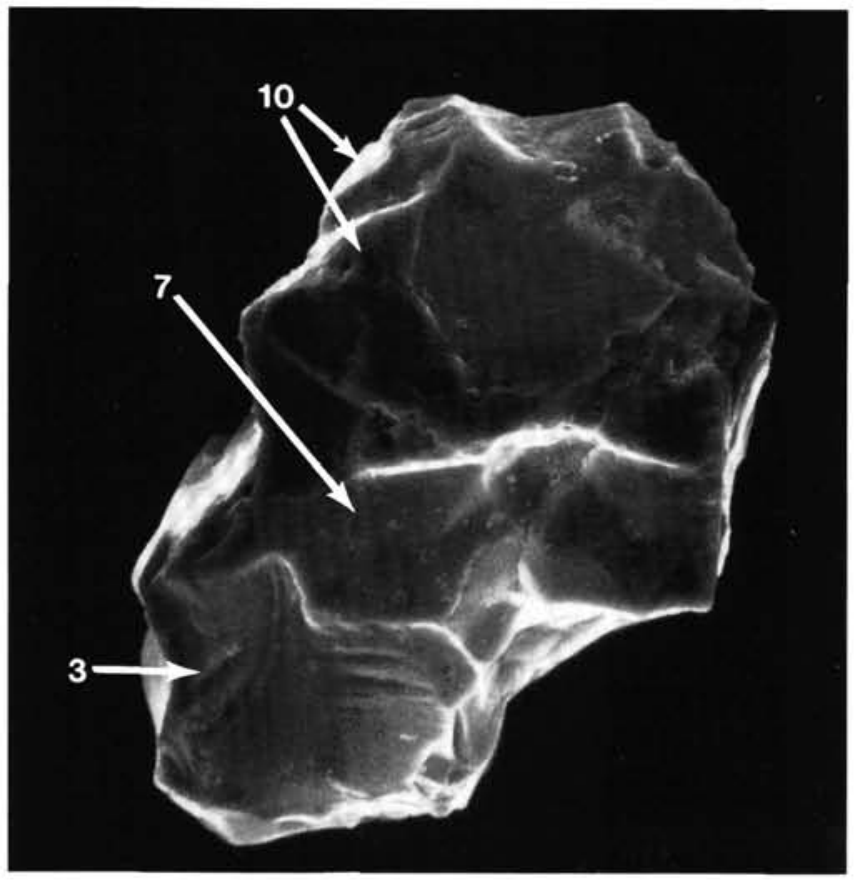

3

Plate 2. SEM photographs of intermediate end member very fine quartz sand. Bar scale on each photograph represents $20 \mu \mathrm{m}$. The numbers correspond to features on the SEM photographs. 1. Intermediate grain showing crystalline nodes (10) and grain embayments (7). A portion of the grain is covered by a smooth layer of precipitated silica (9). Sample 113-693A-33R-1, 90-95 cm. 2. Intermediate grain showing high relief, breakage blocks (4), crystalline nodes (10), and grain embayments (7). Sample 113-696B-20R-1, 75-77 cm. 3. Intermediate grain showing high relief, large-scale conchoidal fractures (3), crystalline nodes (10) and grain embayments (7). Sample 113-694C-10X-CC, 34-36 cm. 4. Intermediate grain showing high relief, crystalline nodes (10), grain embayments (7), and microfractures (2). Sample 113-696B-25R-1, 107-109 cm. 

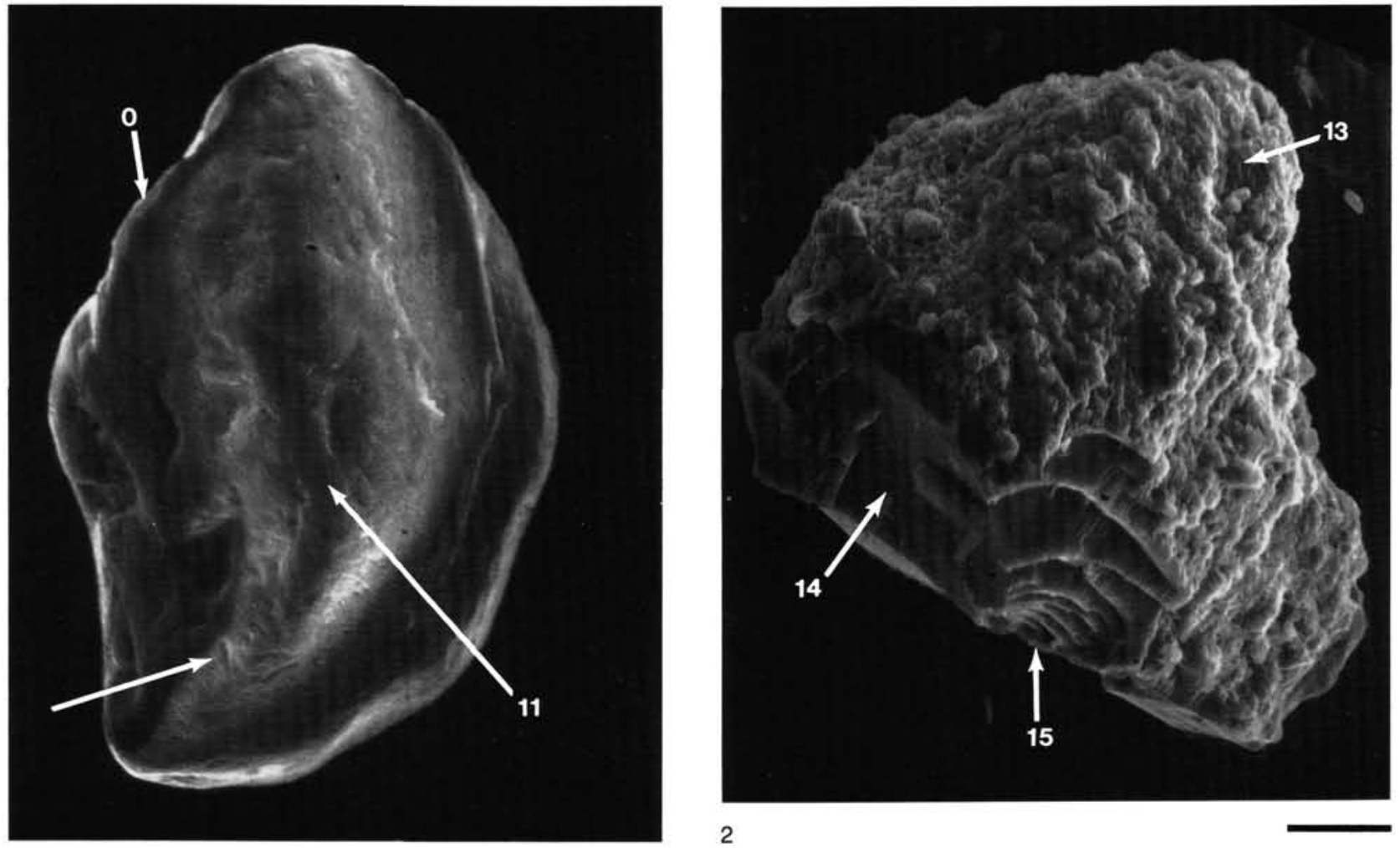

1
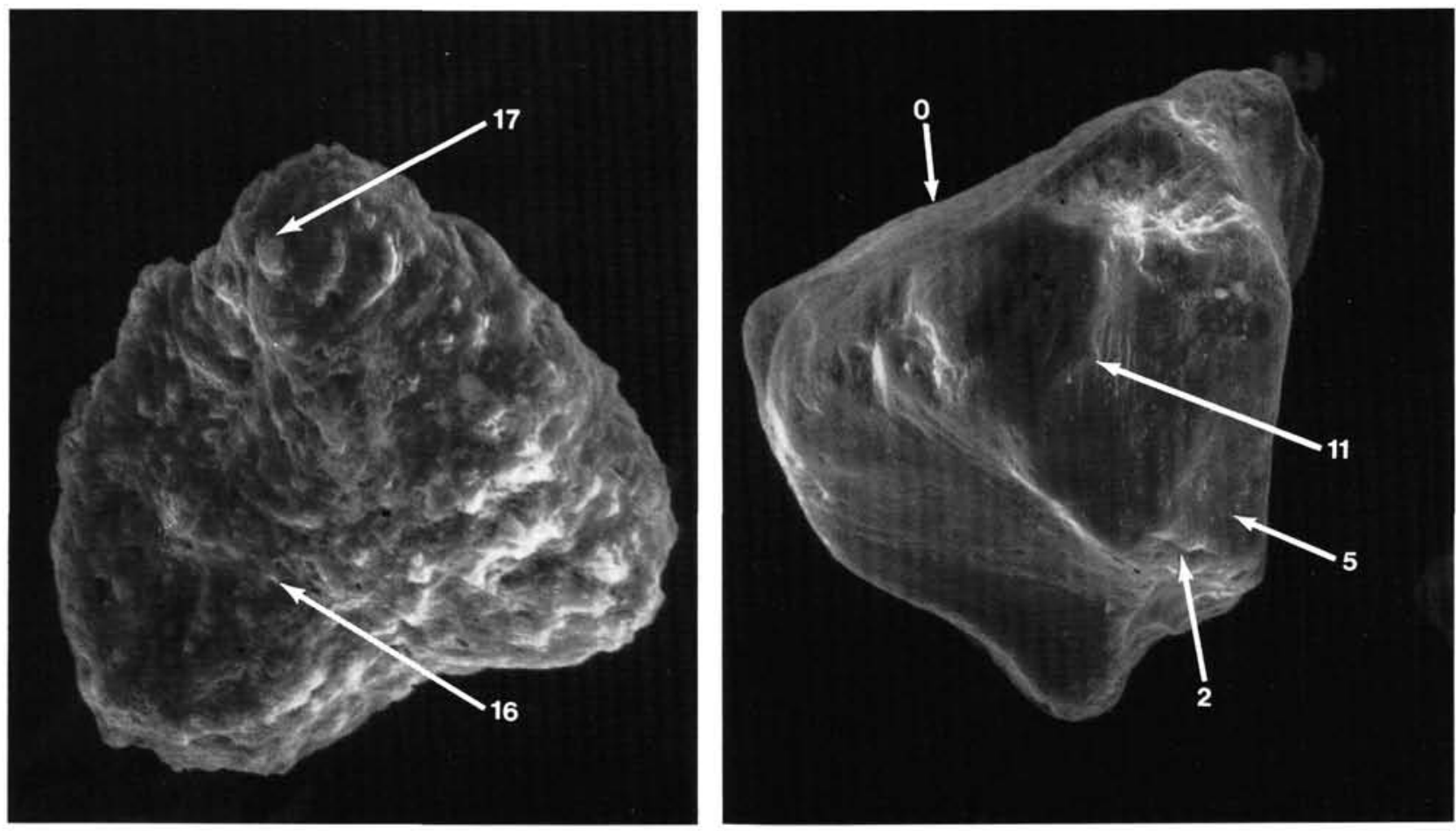

4

Plate 3. SEM photographs of rounded end member very fine quartz sand. Bar scale on each photograph represents $20 \mu \mathrm{m}$. The numbers correspond to features on the SEM photographs. 1. Rounded grain showing low relief, abraded edges (0), flat and hummocky sheets of amorphous silica (11), and abrasion pits (12). Sample 113-693A-13R-2, $80-84 \mathrm{~cm}$. 2. Rounded and subsequently fractured grain showing irregular precipitation and dissolution topography (13). Fresh conchoidal fractures (14) with arc-shaped steps (15). Sample 113-694B-3H-7, 9-11 cm. 3. Rounded grain showing irregular dissolution and precipitation topography. Silica dissolution features (16) and caps of amorphous silica (17). Sample 113-696A-9H-4, 111-115 $\mathrm{cm}$. 4. Rounded and abraded grain showing abraded edges (0), amorphous flat sheets of silica (2), microfractures (11), and comminution debris (5). Sample 113-695A-5H-2, 108-112 cm. 